\title{
Late Pennsylvanian carbonate platform facies and coral reef: new insights from southern China (Guizhou Province)
}

\author{
Marine Maillet ${ }^{1} \mathbb{D} \cdot$ Wen-Tao Huang ${ }^{2} \cdot$ Xiao $\mathrm{Li}^{2} \cdot$ Zhen-Yuan Yang $^{2} \cdot$ Chang-Qing Guan $^{2} \cdot$ Yong-Li Zhang $^{2}$. \\ En-Pu Gong ${ }^{2} \cdot$ Katsumi Ueno $^{3} \cdot$ Elias Samankassou $^{1}$
}

Received: 8 January 2020 / Accepted: 21 October 2020 / Published online: 10 November 2020

(c) The Author(s) 2020

\begin{abstract}
The Pennsylvanian is characterized by intense paleoenvironmental changes related to glacio-eustatic sea-level fluctuations and major tectonic events, which affected the evolution of biocommunities. Most known Pennsylvanian tropical reefs and mounds are predominantly composed of calcareous algae (e.g. phylloid algae, Archaeolithophyllum), calcareous sponges, fenestrate bryozoans, Tubiphytes, and microbialites. However, in Houchang (southern China), the Late Pennsylvanian carbonate platform records a large coral reef lacking any analogs in age (Gzhelian), size (80-100 m thick) and composition (high biodiversity). The large coral reef developed at the border of the Luodian intraplatform basin. The intraplatform basin is characterized by the deposition of green algal grainstone, coated grain grainstone and bioclastic packstone, grainstone, floatstone and rudstone in shallow-waters. In the deep-water shelf, lithofacies are composed of burrowed bioclastic wackestone, microbioclastic peloidal packstone, grainstone, and fine-grained burrowed wackestone and packstone. In this context, the coral reef developed on a deep-shelf margin, in a moderate to low energy depositional environment, below the FWWB. The scarcity of Pennsylvanian coral reefs suggests global unfavorable conditions, which can be attributed to a complex pattern of several environmental factors, including seawater chemistry (aragonite seas), paleoclimatic cooling related to continental glaciation, and the biological competition with the more opportunistic and adaptive phylloid algal community that occupied similar platform margin paleoenvironments. The existence of the large Bianping coral reef in southern China, as well as a few additional examples of Pennsylvanian coralliferous bioconstructions, provides evidence that coral communities were able to endure the Late Paleozoic fluctuating paleoenvironmental conditions in specific settings. One of such settings appears to have been the deep shelf margin, where low light levels decreased competition with the phylloid algal community.
\end{abstract}

Keywords Pennsylvanian $\cdot$ Kasimovian-Gzhelian $\cdot$ Coral reef $\cdot$ Carbonate platform

\section{Introduction}

The Carboniferous is a critical interval in Earth History, characterized by major cyclic paleoenvironmental changes such as climate, seawater chemistry and high frequency glacio-eustatic sea-level fluctuations, which directly influenced

Marine Maillet

marine.maillet@unige.ch

1 Department of Earth Sciences, University of Geneva, Rue des Maraîchers, 13, 1205 Geneva, Switzerland

2 Department of Geology, Northeastern University, Wenhua Road 3-11, Heping district, Shenyang 110819, Liaoning, People's Republic of China

3 University of Fukuoka, 8-19-1 Nanakuma, Jonan-ku, Fukuoka 814-0180, Japan the evolution and development of biological communities (Brand 1989; Heckel et al. 2007; Heckel 2008; Davydov et al. 2012; Wang et al. 2013). The Mississippian is considered as a period of metazoan reef-building collapse subsequent to the Late Devonian extinction events (Sandberg et al. 1988; Thompson and Newton 1988; Buggisch 1991; Webb 2002; Kaiser et al. 2015; Barash 2017). During the Pennsylvanian and Permian, new types of organic carbonate buildup communities evolved that were composed of various combinations of calcareous algae, bryozoans, calcareous sponges and microbialites (Copper 1986, 2002; West 1988; Wahlman 2002; Webb 2002). Sparse Carboniferous shallowwater buildups containing corals have been described, but corals generally played only minor roles in their construction (Wilson 1963; Wahlman 2002; Ogar 2012). 
Sparse large Pennsylvanian coral-rich reefs have been described, such as the Bashkirian-Moscovian reefs of the Akiyoshi Group in Japan, which contain abundant tabulate and rugose corals (Ota 1968; Nagai 1985; Fagerstrom 1987; Sugiyama and Nagai 1990, 1994; Nakazawa 1997; Wahlman 2002), and the Kasimovian-Gzhelian coral reef (80-100 m thick and $700 \mathrm{~m}$ wide) reported in Guizhou, southern China (Zhang et al. 2010; Gong et al. 2012). The well-developed coral reef reported in Bianping (Ziyun County, Guizhou) is considered to be the largest Pennsylvanian organic carbonate buildup with a coralliferous reefal framework in the world (Zhang et al. 2010). To understand the overall context leading to the development of this exceptional reef growth (platform architecture and environmental conditions), two sections located in Zhongxinzhai and Brickyard villages, respectively (Houchang, Ziyun, Guizhou), have been investigated, and selected samples have been analyzed for petrographic characteristics, biostratigraphic age (fusulines), and chemostratigraphy ( $\mathrm{Sr}$ isotopes). The existence of the large Pennsylvanian coral reef, which persisted only in a specific setting as shown in the present study, holds the potential to improve our current understanding of the collapse and recovery of coral reefs.

\section{Geological settings}

\section{Southern China paleogeography}

During the Pennsylvanian and Early Permian (Asselian-Sakmarian), in the Guangxi Autonomous Region and Guizhou Province (southern China), sedimentation occurred in the Dian-Qian-Gui Basin at the passive continental margin of the Yangtze Craton. During the Carboniferous, the Dian-Qian-Gui Basin records several elongate depressions (SW-NE axis), separated by more broad structural highs, resulting from pre-Carboniferous syndepositional faulting (Tsien et al. 1988; Shen 2002). During the Late Pennsylvanian-Early Permian (Asselian), the area consisted of a tropical epicontinental sea, dominated by carbonate platform facies associated with intraplatform depression facies (Shen and Qing 2010; Wang et al. 2013; Fig. 1). During the latest Sakmarian, a major sea-level fall occurred, which produced a series of coal-bearing strata and an extensive sedimentary hiatus throughout South China (Wang et al. 2013).

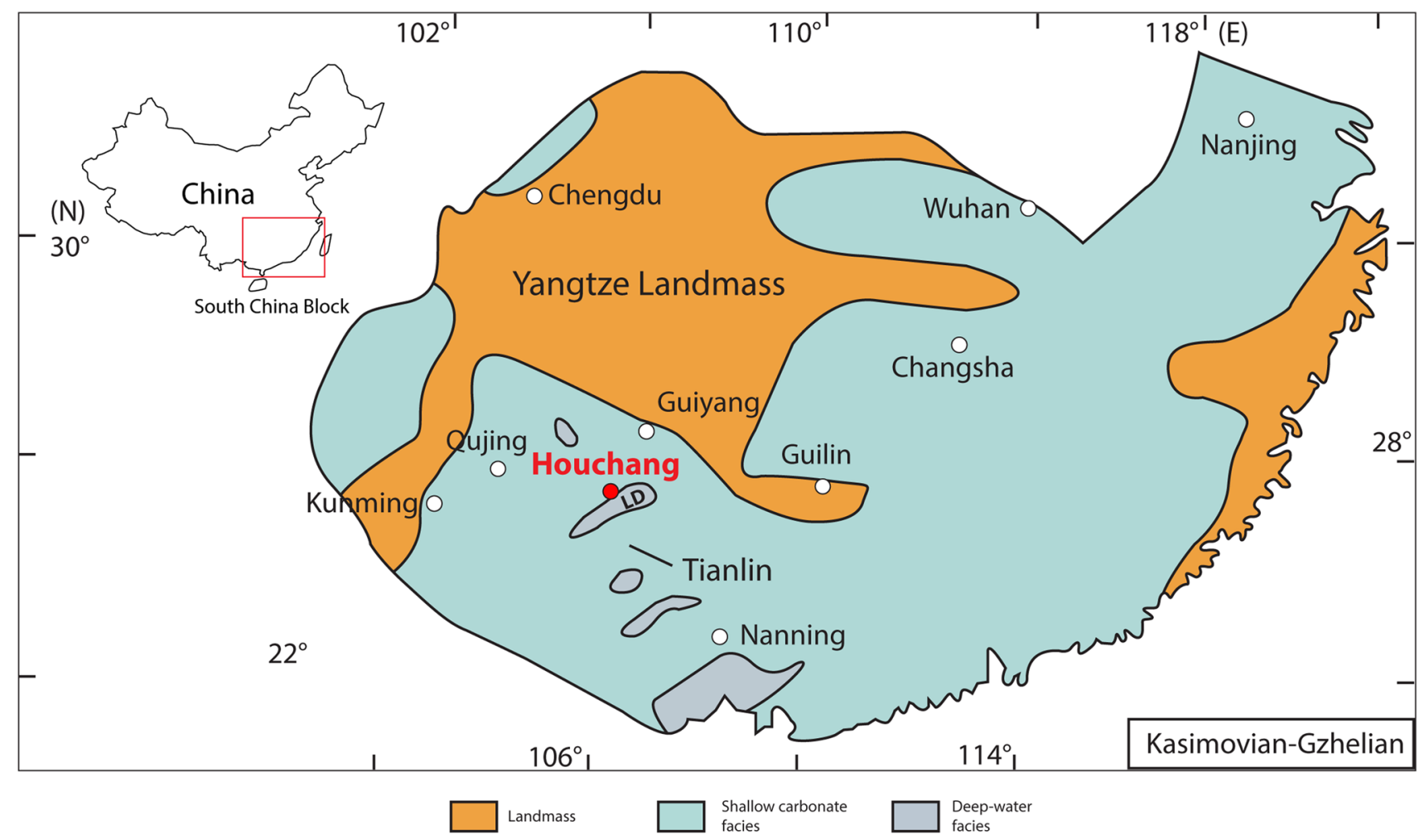

Fig. 1 Late Pennsylvanian paleogeographic map of southern China (modified from Feng et al. 1998; Yao and Wang 2016). Ziyun (Guizhou) is the study area. $L D$ Luodian Basin 


\section{Study area}

The study area around the town of Houchang (Ziyun County, Guizhou Province) exhibits folded Devonian to Triassic carbonate rock units (Fig. 2). During the Carboniferous, the Houchang area was located at the margin of the Luodian intraplatform basin (Fig. 1), where numerous bioconstructions have been reported (Yao and Wang 2016).

Late Pennsylvanian bioconstructions include microbial mounds (Huang et al. 2019), sponge reefs (Tan 1991; Yao and Wang 2016), phylloid algal reefs (Gong et al. 2007a, b), Tubiphytes reefs (Chang et al. 2008; Guan et al. 2010; Yao and Wang 2016), a small mud mound (Chang et al. 2008; Gong et al. 2012) and a large coral reef (Zhang et al. 2010; Gong et al. 2012). All of these bioconstructions were roughly interpreted as growing at the platform margin (Table 1), but the sedimentary context was not constrained.

The Late Moscovian microbial mounds (Zhongxinzhai and Lumazhai villages, Houchang), measuring 30-200 m wide and 15-19 m thick, are composed of microbial boundstone characterized by stromatolitic structures, irregular oncoid-like forms and wrinkle structures (unknown microbes). Microbial boundstone co-existed with tubeshaped algae, crinoids, bryozoans, brachiopods, corals (Ivanovia, not to be confused with the synonymous phylloid alga common in Pennsylvanian deposits), chaetetids, phylloid algae, and numerous calcimicrobes including Girvanella, Ortonella, Wetheredella-like, Palaeomicrocodium-like, and some problematic calcimicrobes (Huang et al. 2019). The microbial mounds might have formed in the euphotic zone, with shallow-water, normal salinity, and under relatively high-energy conditions (Huang et al. 2019).

The Late Kasimovian-Gzhelian calcisponge reefs (Wengdao village, Houchang) are 100-200 m wide and 8-12 m thick. Reef-building organisms are dominated by chaetetid sponges (Solenopora), associated with green algae, solitary rugose corals, bryozoans, brachiopods, crinoids and foraminifera. The calcareous sponge reefs are currently interpreted as growing at a very shallow platform margin (Tan 1991; Yao and Wang 2016).

The Gzhelian phylloid algal reefs (Wengdao and Bianping villages, Houchang) are $30-50 \mathrm{~m}$ wide and $2-8 \mathrm{~m}$ thick. They are built mainly by phylloid algae, characterized by single cup-shaped, cabbage-shaped and clustering cupshaped morphologies, associated to brachiopods, foraminifera, corals, crinoids, bryozoans, gastropods and Tubiphytes (Fan and Rigby 1994; Gong et al. 2007a, b; Guan et al. 2010; Gong et al. 2012; Yao and Wang 2016). These phylloid algal reefs developed below the FWWB, in a moderate energy environment, within the photic zone (Gong et al. 2007a, b).

The Gzhelian Tubiphytes patch reefs (Bianping village, Houchang) are 0.7-3 m wide and 0.3-0.5 m thick and are

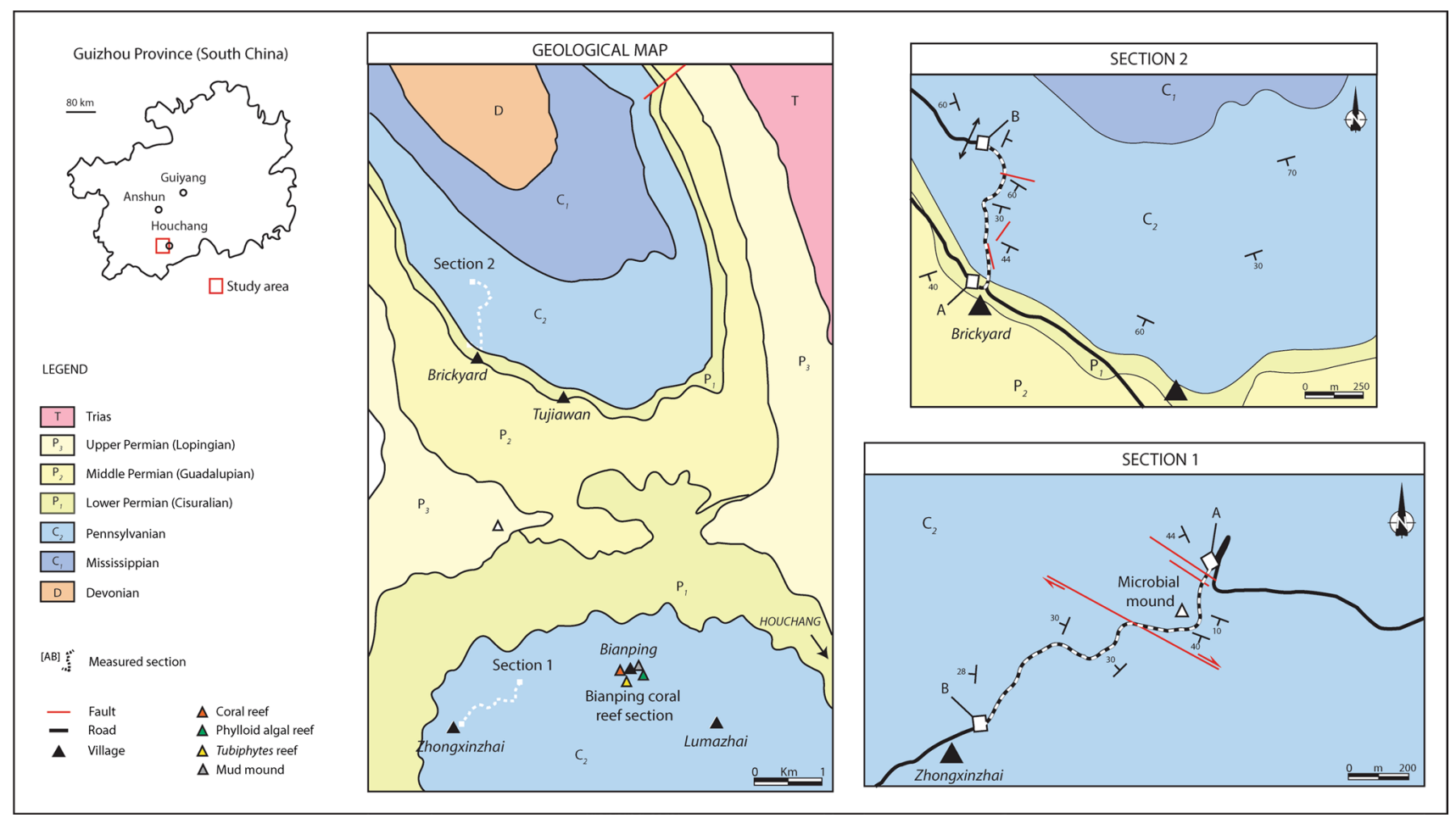

Fig. 2 Geological map of the Houchang area (Ziyun, Guizhou), showing locations of measured sections 1 and 2. On the right side are closer maps showing the paths of the two sections, with the bases of the measured sections are in A, and the tops of the sections in B 


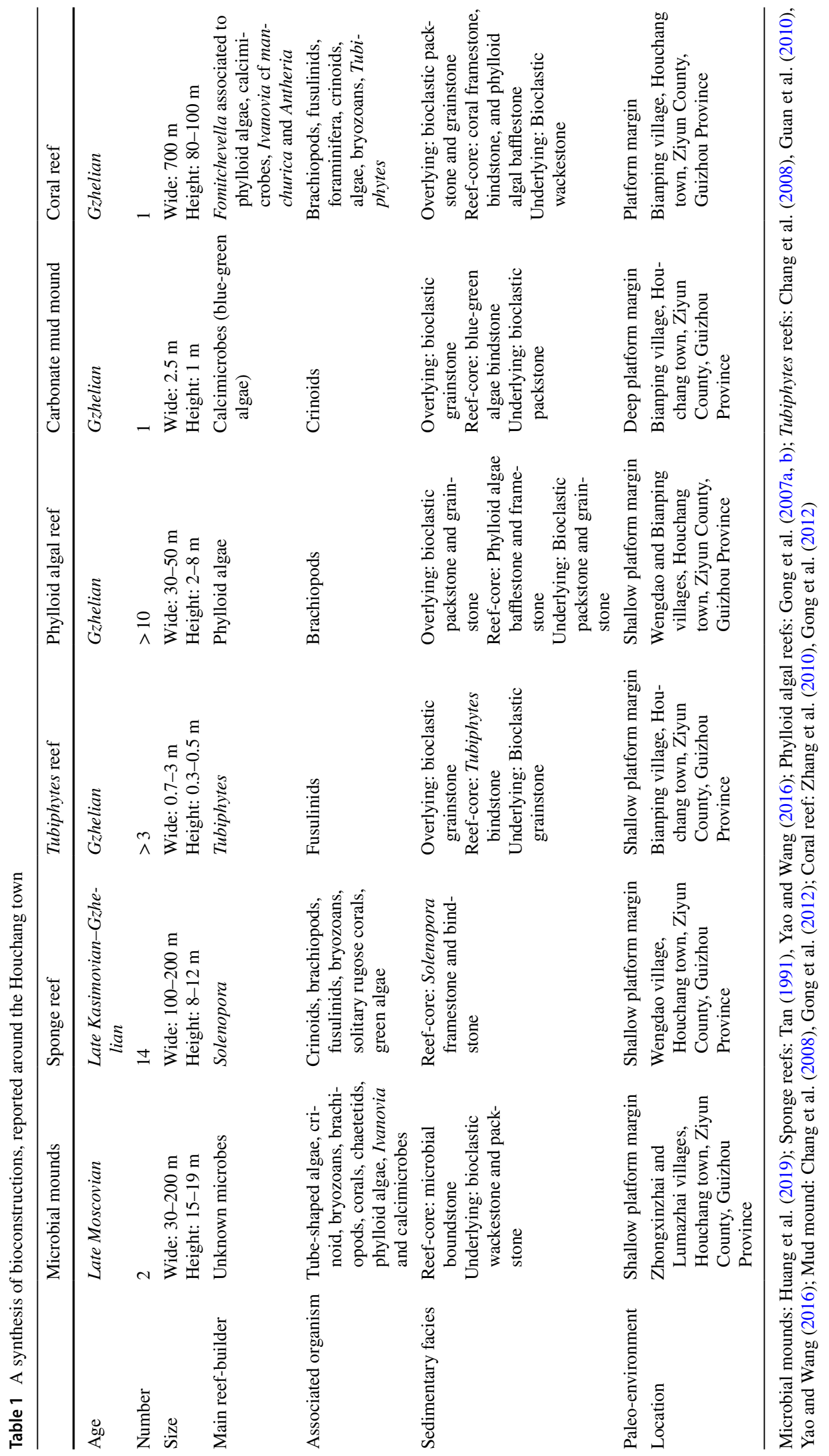


dominated by Tubiphytes (Guan et al. 2010), which might represent calcimicrobes during this time (Flügel 2010; Yao and Wang 2016). These reefs were interpreted to have grown at a shallow platform margin (Yao and Wang 2016).

The Gzhelian carbonate mud mound (Bianping village, Houchang) is built mainly by calcimicrobes (Yao and Wang 2016) associated with crinoids. It measures $2.5 \mathrm{~m}$ width and $1 \mathrm{~m}$ thickness. The mud mound was interpreted as growing at a deeper platform margin (Yao and Wang 2016).

The Gzhelian coral reef (Bianping village, Houchang) is 80-100 thick and about $700 \mathrm{~m}$ wide, and was constructed by large branching rugose colonial corals (Fomitchevella sp.). Other reef-builders, such as phylloid algae, the corals Ivanovia cf. manchurica and Antheria sp., and microbialites constructed an initial reef facies and substrate for the branching corals to colonize (Fig. 3). Associated organisms include brachiopods, fusulines (Triticites and few Quasifusulina; Gong et al. 2004; Guan et al. 2004; Zhang et al. 2010; Gong et al. 2012), other undetermined smaller foraminifera, crinoids, algae, bryozoans and Tubiphytes (Zhang et al. 2010; Gong et al. 2012). Currently, the depositional environment of the Bianping coral reef is not well constrained.

\section{Global paleoclimate and glacio-eustatic fluctuations}

The Carboniferous is commonly regarded as a time of global greenhouse-icehouse climate transition. Recent studies suggest multiple pulses of glaciation and deglaciation (Fielding et al. 2008a), with resulting high-frequency sea-level fluctuations (Ross and Ross 1987, 1988; Haq and Schutter 2008).

\section{Late Paleozoic Ice Age}

The Late Paleozoic Ice Age (LPIA) began with short-lived Mississippian (Tournaisian and Late Viséan) localized glacial events (e.g. South America, Isbell et al. 2003; Caputo et al. 2008; Fielding et al. 2008a; Henry et al. 2008). The onset of widespread glaciation occurred at the Viséan-Serpukhovian boundary in Gondwanaland (present-day South America and eastern Australia, Fielding et al. 2008a). During the earliest Bashkirian, Icehouse conditions expanded further, becoming widespread across South America (Holz et al. 2008; Rocha-Campos et al. 2008; Henry et al. 2008) and Australia (Fielding et al. 2008b; Mory et al. 2008). Further expansion of continental glacial ice centers in Southern Africa (Stollhofen et al. 2008; Isbell et al. 2008), Oman and Saudi Arabia (Martin et al. 2008) occurred at the Bashkirian-Moscovian boundary. During the early late Pennsylvanian, isotopic and paleobotanical records suggest a period of relative climatic warming (Frank et al. 2008; Pfefferkorn et al. 2008). Then, the latest Pennsylvanian-earliest Permian interval corresponds to a widely expanded glacial phase, with the growth of large ice sheets across Gondwana and accumulation of ice in the northern hemisphere (Rygel et al. 2008). Ice sheets are inferred to have been at their maximum extent around the Pennsylvanian-Permian boundary and persisted until the Late Sakmarian (Rygel et al. 2008), focused on Antarctica, Australia, southern Africa and South America (Fielding et al. 2008a).

\section{Glacio-eustatic fluctuations}

Throughout the Pennsylvanian, glacio-eustatic fluctuations are of high amplitude, varying from 10 to $\sim 120 \mathrm{~m}$ (Ross and Ross 1987, 1988; Maynard and Leeder 1991; Haq and Schutter 2008; Rygel et al. 2008; Davydov et al. 2012), with a periodicity within the Milankovitch ranges (Harrison et al. 1979; Ross and Ross 1987; Heckel et al., 2007). In detail, from the latest Viséan-earliest Pennsylvanian, strata exhibit evidence of glacio-eustasy of 40-100 m (Rygel et al. 2008). Conversely, during the Mid-Pennsylvanian, glacio-eustatic fluctuations were less than $40 \mathrm{~m}$, prior to reaching magnitudes of 100-120 m during the Late Pennsylvanian-earliest Permian (Rygel et al. 2008).

\section{Methods}

\section{Petrography}

The dataset consists of three stratigraphic sections. Two sections were measured in the Zhongxinzhai (section 1) and Brickyard villages section 2; Fig. 4), respectively, which are five $\mathrm{km}$ apart. The third section was measured along the large Bianping coral reef (Gong et al. 2004, 2012; Zhang et al. 2010).

Thin sections from 123 samples were analyzed using a petrographic microscope. Lithofacies were classified following Dunham (1962) and Embry and Klovan (1971) and grouped according to grain assemblages and texture to interpret the depositional environments.

\section{${ }^{87} \mathrm{Sr} /{ }^{86} \mathrm{Sr}$ dating}

Twenty-eight carbonate samples were selected for Sr isotope analyses. Powders of bulk samples were collected, avoiding veins during drilling. The ratios were measured using a Thermo Neptune PLUS Multi-Collector inductively coupled plasma mass spectrometer, in static mode (University of Geneva). The method follows that described in Samankassou et al. (2018). Due to a systematic difference between measured and nominal standard ratios of the SRM987 of ${ }^{87} \mathrm{Sr} /{ }^{86} \mathrm{Sr}$ (0.710248), the internally corrected ${ }^{87} \mathrm{Sr} /{ }^{86} \mathrm{Sr}$ values were additionally corrected by a value of $-0.025 \%$ o per amu for external fractionation (McArthur et al. 2001). 

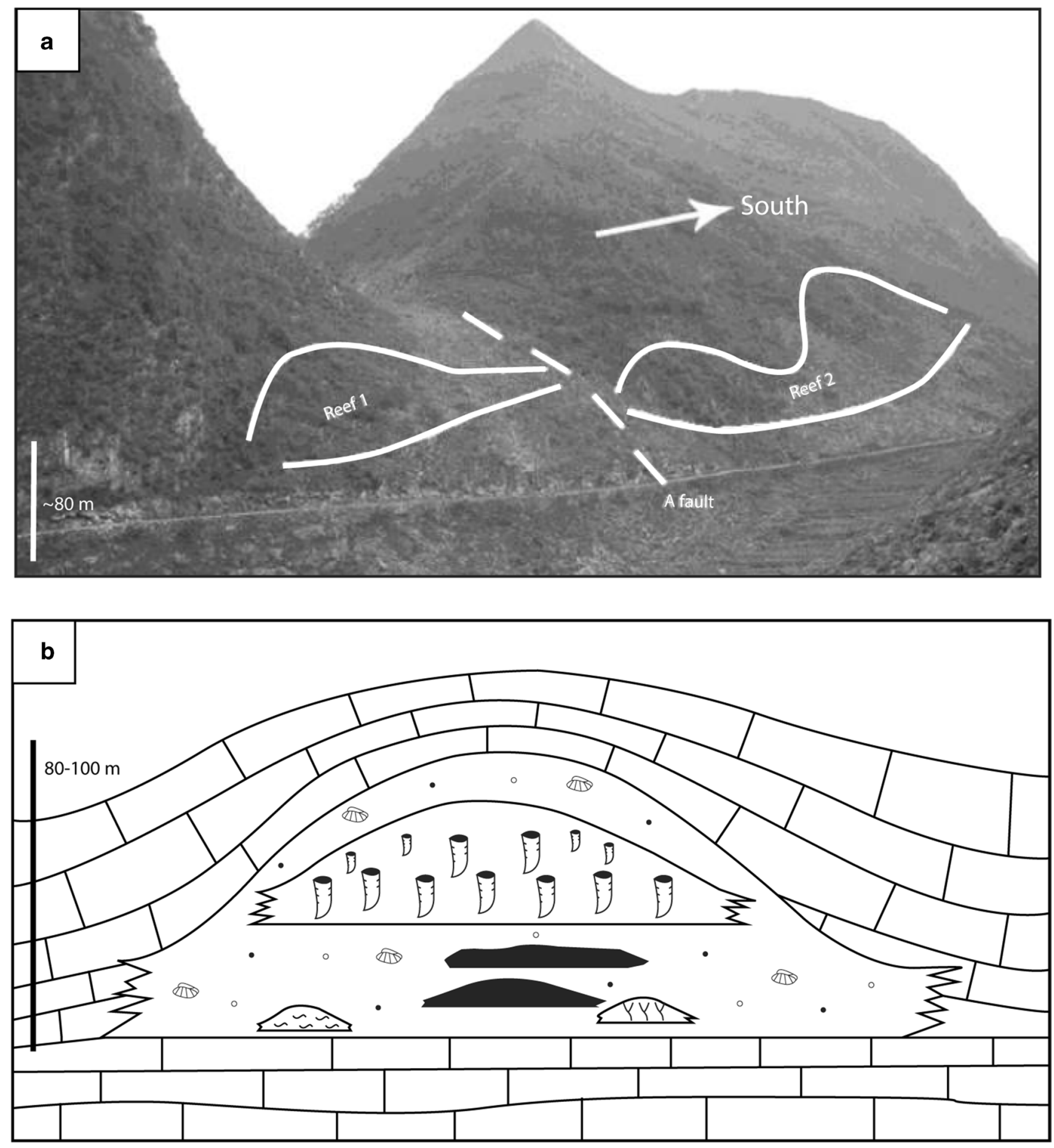
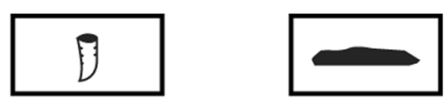

Ivanovia cf. manchurica

Fig. 3 a Outcrop of the Bianping coral reef. The two exposures (Reef 1 and Reef 2) likely represent the same reef complex, separated by an apparent fault. b Sketch diagram of the Bianping coral reef showing

Fomitchevella

Calcimicrobes

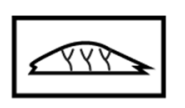

Phylloid algae

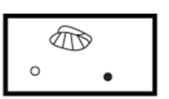

Bioclast

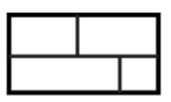

Bedded limestone

the composition and distribution of reef-building biota and associated bioclastic facies. Modified from Gong et al. (2012) 

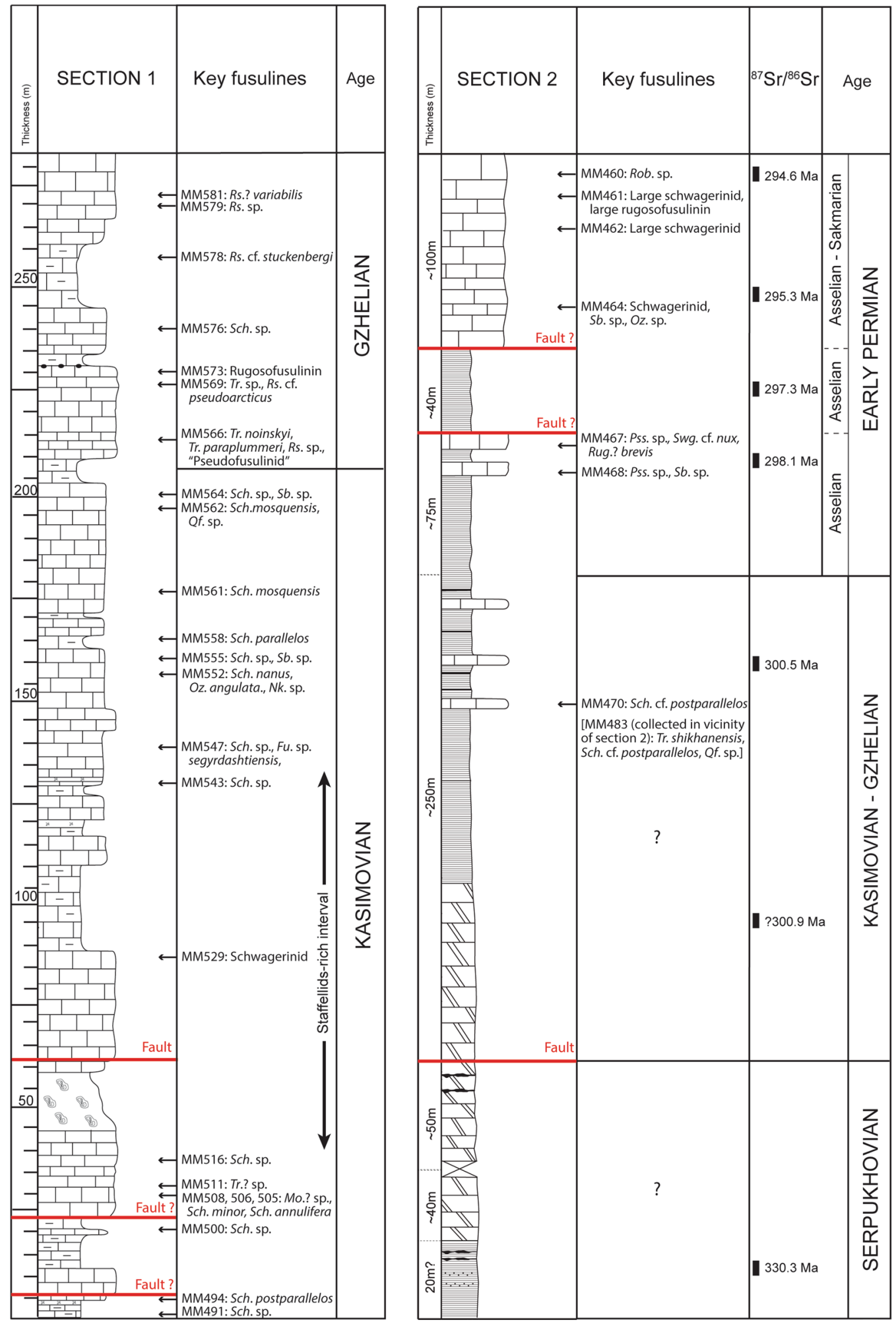

Dolomitized limestone

$\square$ Bioclastic limestone

기 Muddy limestone

Calcisiltite

Mudstone

Marl

_ Chert belt

- Chert nodule

= Planar lamination

2. Phylloid algal boundstone Microbial mound

Sch.: Schwageriniformis

Mo.: Montiparus

Rs.: Rauserites

Tr.: Triticites

Sb.: Schubertella

Qf: Quasifusulina

Oz:: Ozawainella

Fu.: Fusiella

Nk.: Nankinella

Rug.: Rugosofusulina

Swg.: Schwagerina

Pss.: Pseudoschwagerina

Rob.: Robustoschwagerina

Fig. 4 Measured sections 1 (Zhongxinzhai) and 2 (Brickyard) showing the lithofacies successions, the stratigraphic distribution of agediagnostic key fusuline foraminifera, strontium absolute age dates (section 2 only), and chronostratigraphy. Section 1 is through relatively shallow-water ramp facies, and section 2 is through a relatively deeper water slope to basin succession 


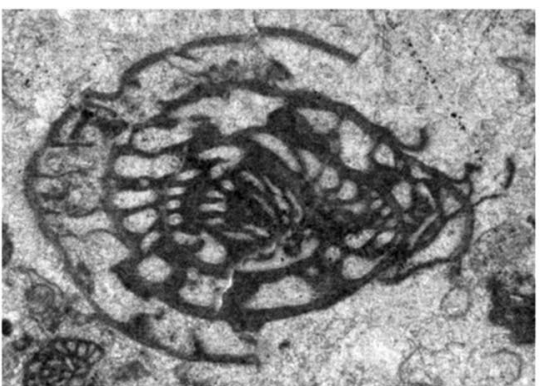

a
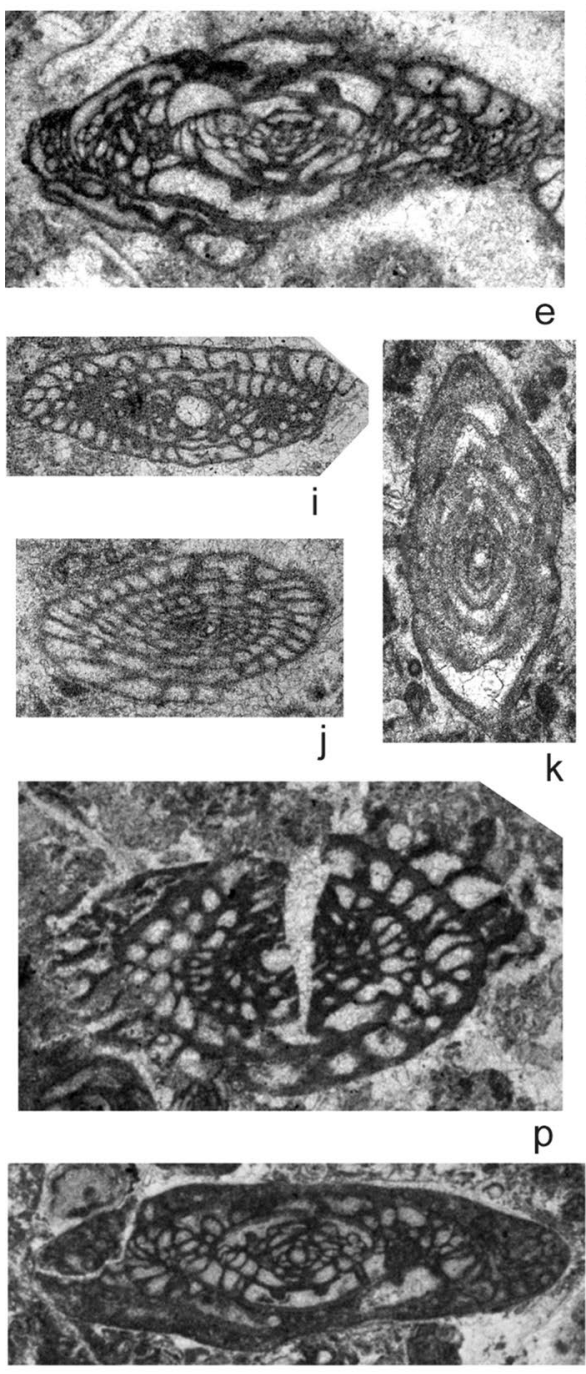

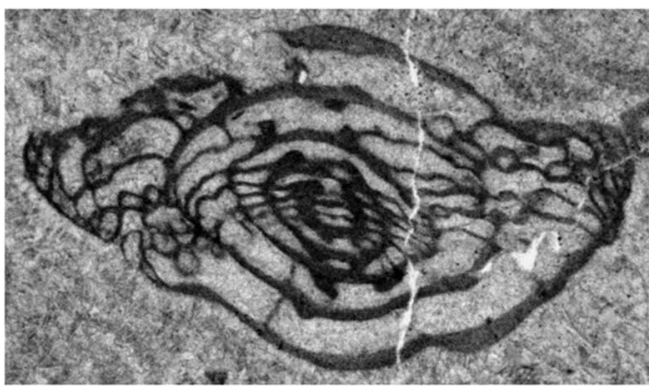

b

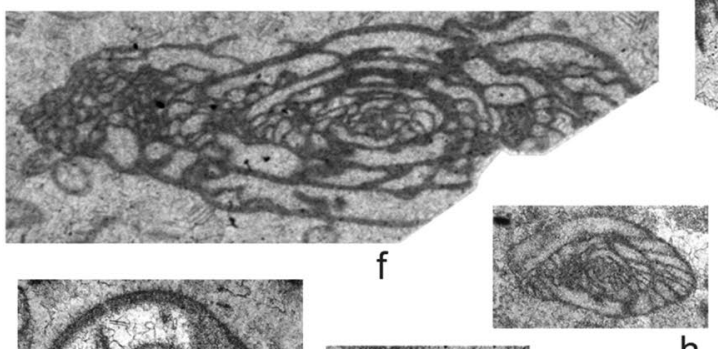

$\mathrm{h}$
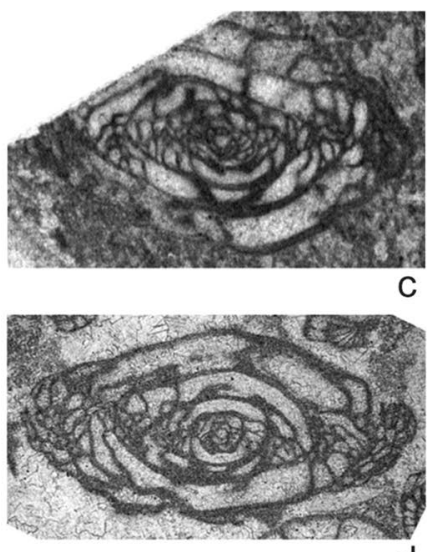

d
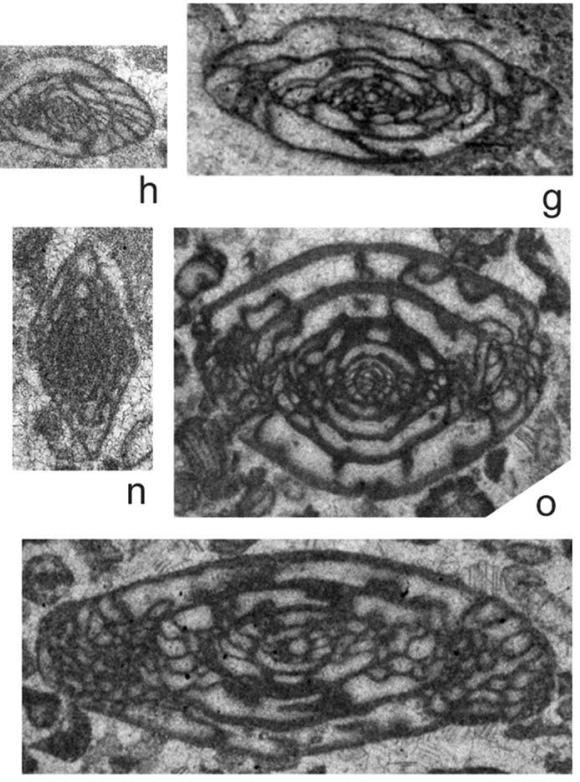

r

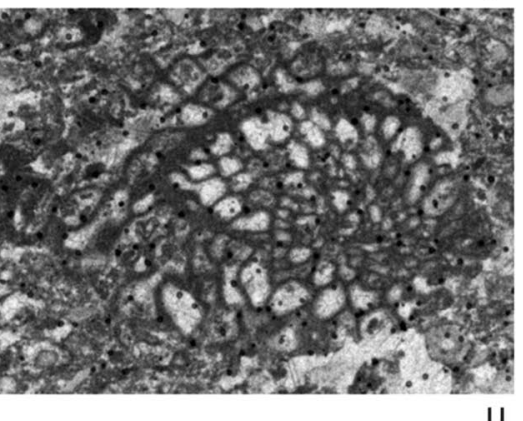

u

$a \sim g, i, o \sim u$

$h, j \sim n$

\section{Fusuline biochronology}

A total of 46 fusulinid samples from section 1 and seven samples from section 2 were investigated to establish fusulinid-based chronostratigraphic framework (Fig. 4). Fusulines are the most important biostratigraphic index fossils used in this analysis, and were recently calibrated with high-precision $\mathrm{U}-\mathrm{Pb}$ zircon absolute age-dates in the Carboniferous successions of the Donets Basin and Urals (Davydov et al. 2010; Schmitz and Davydov 2012). 
4Fig. 5 Representative age-diagnostic fusulines from section 1 (Zhongxinzhai). a Montiparus? sp., nearly tangential section, sample MM508. b Schwageriniformis postparallelos (Scherbovich), tangential section, sample MM494B. c Schwageriniformis mosquensis (Rozovskaya), axial section, sample MM561. d Schwageriniformis nanus (Rozovskaya), axial section, sample MM552. e Schwageriniformis parallelos (Scherbovich), axial section, sample MM505. f Schwageriniformis annulifera (Rauzer-Chernousova), axial section, sample MM505. g Schwageriniformis minor (Rozovskaya), axial section, sample MM506. h Schubertella sp., axial section, sample MM555. i Quasifusulina sp., axial section (immature specimen), sample MM562. j Fusiella cf. segyrdashtiensis Davydov in Leven and Davydov (2001), oblique section, sample MM547. k-m Indet. staffellids (k: Reitlingerina? sp., 1: Parastaffelloides? sp., m: Nankinella sp.), all axial sections, k, l: sample MM517, m: sample MM552. n Ozawainella angulata (Colani), axial section, sample MM552. o Triticites paraplummeri Bensh, axial section, sample MM566. p Rauserites cf. pseudoarcticus (Rauzer-Chernousova), oblique section, sample MM569. q Indet. "pseudofusulin" (potentially Ruzhenzevites or Andersonnites), tangential section (fragment), sample MM566. $\mathbf{r}$ Triticites noinskyi Rozovskaya, axial section, sample MM566. s Rauserites? variabilis Rozovskaya, axial section, sample MM581. t Rauserites cf. stuckenbergi (Rauzer-Chernousova), axial section, sample MM578. u Indet. rugosofusulin (potentially Dutkevitchia), diagonal section, sample MM573. Scale bars equal to $1 \mathrm{~mm}$

\section{Age}

\section{Section 1 (Zhongxinzhai)}

Fusulines occur throughout the Zhongxinzhai section (Figs. 4, 5). The lower, about 200 m-thick succession in this section is characterized by the occurrences of species of Schwageriniformis, including S. minor, S. annuifera, S. nanus, S. parallelos, P. postparallelos, and S. mosquensis (Fig. 5b-g). Similar Schwageriniformis-dominant assemblages have been widely reported from the middle-late Kasimovian of the Tethyan region (e.g. Leven and Davydov 2001; Leven 2009; Orlov-Labkovsky and Bensh 2015). From 40 to $133 \mathrm{~m}$ above the base of the section, schwagerinid fusulines are rare and staffellid fusulines are common, indicating more inner shelf, restricted marine paleoenvironments (Fig. 5k, 1). From 220 m upsection, faunal associations change significantly. Schwageriniformis becomes rare and instead Rauserites becomes more common, including $R$. cf. stuckenbergi, $R$. cf. pseudoarcticus, and $R$.? variabilis (Fig. $5 \mathrm{p}, \mathrm{s}, \mathrm{t}$ ). Triticites paraplummeri and T. noynskyi are also associated with them (Fig. 5o, r). Though represented by poor specimens in sections, there also occur some larger schwagerinids that are somewhat similar to Ruzhenzevites or Andersonnites (Fig. 5q) and Dutkevitchia (Fig. 5u). These forms are indicative of a Gzhelian age in a broad sense (e.g., Leven 2009; OrlovLabkovsky and Bensh 2015). Therefore, fusulines indicate that section 1 ranges in age from the middle Kasimovian to Gzhelian (Fig. 4).

\section{Section 2 (Brickyard)}

Samples collected at Brickyard are poor in fossil content compared to the Zhongxinzhai section, with fusulines occurring at only a few horizons (Figs. 4, 6). Especially in the lower part of the section, carbonates are entirely dolomitized, which hampered biostratigraphic age-dating. Therefore, dating for this section relied on both $\mathrm{Sr}$ isotope chemostratigraphy and fusuline biochronology. The ${ }^{87} \mathrm{Sr} /{ }^{86} \mathrm{Sr}$ ratios range from 0.70798 to $0.70791 .{ }^{87} \mathrm{Sr} /{ }^{86} \mathrm{Sr}$ values from some key samples are summarized in Table 2 . These results indicate ages ranging from the Serpukhovian (330 Ma) to Asselian (earliest Permian) (296 Ma; Howarth and McArthur 1997; McArthur et al. 2001, 2012). In the lower part of section 2, where fossils occurrences are poor, Sr isotope analysis was more important than biostratigraphy, but age dates based on isotopes and biostratigraphy consistently agreed in the middle and upper parts of the section (Fig. 4).

In the lower part of section 2, sample MM477B gives an age of ca. $330 \mathrm{Ma}$ based on $\mathrm{Sr}$ isotope geochronology. The data show that this stratigraphic interval probably corresponds to the Serpukhovian. Two samples (MM470 and MM483; the latter was collected in the vicinity of section 2) from the middle of the section contain Triticites shikhanensis, Schwageriniformis cf. postparallelos, and Quasifusulina sp. (Fig. 6a-c). This assemblage is similar to that seen in the Kasimovian part of section 1. Moreover, a Gzhelian age (300.5 Ma) is obtained from sample MM469 by the Sr isotope dating. Thus, the middle part of section 2 is correlated to the Kasimovian and possibly to the Gzhelian. Higher up the section, two samples (MM467 and MM468) collected from thin limestone intervals contain Pseudoschwagerina sp., Rugosofusulina brevis, Schwagerina cf. nux, and others (Fig. 6f-i). An Asselian age is demonstrated for the limestones by these fusulines (Leven and Scherbovich 1978; Leven 2009). In the uppermost 100 m-thick part of section 2 , represented by bioclastic limestone, four samples were examined for age determination by fusulines. Sample MM464 yields schwagerinids and Ozawainella sp. (Fig. 6d). Although the youngest stratigraphic occurrence of the genus Ozawainella has not been much discussed among fusuline workers until now, available data suggest that its last occurrence is in the Asselian (Leven and Scherbovich 1978; Leven et al. 1992). This implies that the level of sample MM464 is pre-Sakmarian. Above this level, a large schwagerinid having a peculiar style of septal fluting occurred in sample MM461 (Fig. 6k). Although the thin-section of the specimen is very poor, it is probably referable to an advanced large Dutkevitchia species, such as D. complicata, D. splendida, or D. devexa, all of which have large shells with characteristic irregular-shaped bubble-like septal flutings in the axial ends of their tests. Just above, sample MM460 contains a large spherical fusulinid with loose coiling, a thick 


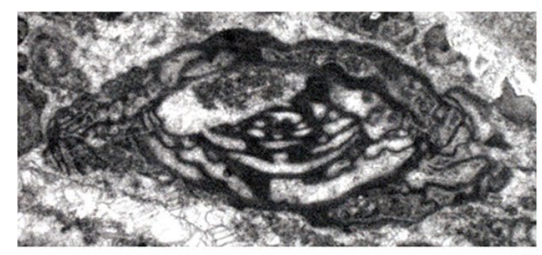

a

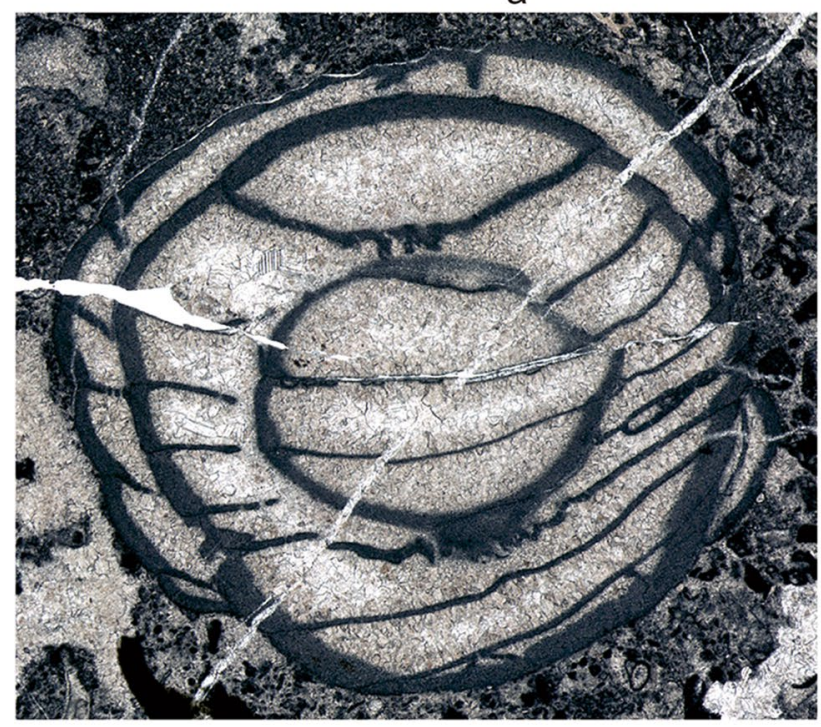

j $\sim 1$

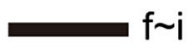

$a \sim c$

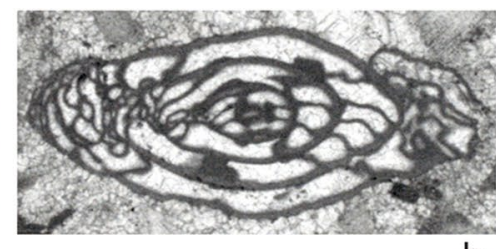

b
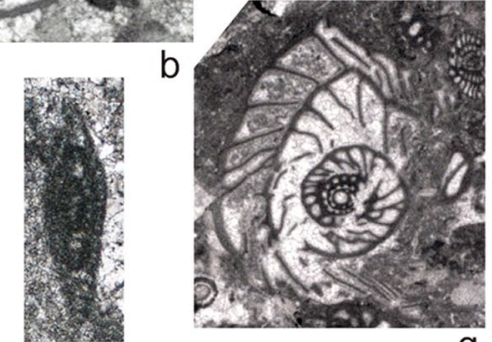

:
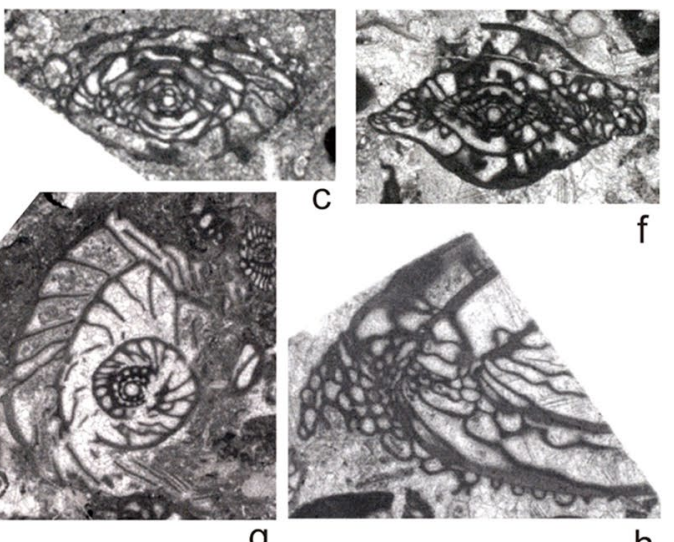

$\mathrm{g}$

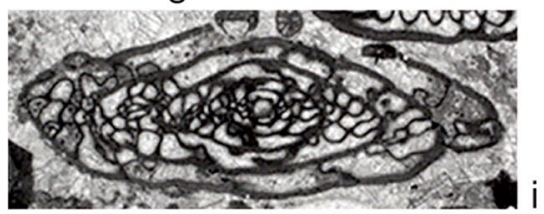

h
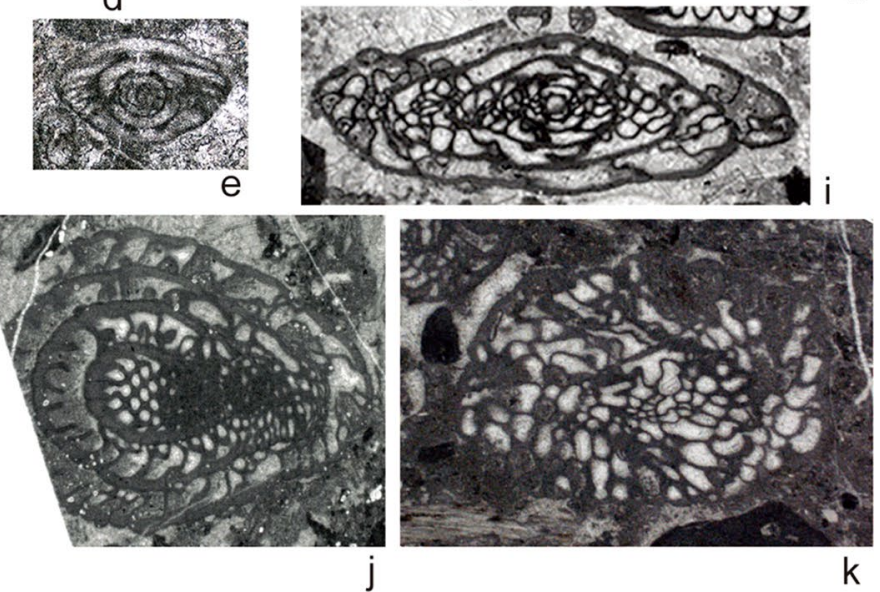

Pseudoschwagerina sp., g: sagittal section, sample MM468, h: tangential section (fragment), sample MM467. i Rugosofusulina brevis Leven and Scherbovich, axial section, sample MM467. j Indet. schwagerinid ("Pseudofusulina"), diagnonal section, sample MM462. k Indet. rugosofusulinin (probably advanced Dutkevitchia), diagonal section, sample MM461. I Robustoschwagerina sp., tangential section, sample MM460. Scale bars equal to $1 \mathrm{~mm}$

Kobayashi and Altiner 2008; Leven 2009). The overall age assessment based on fusulines in section 2 is in good agreement with the $\mathrm{Sr}$ chemostratigraphic data. The latter also suggests an earliest Permian age (Asselian) for the upper part of the section (Table 2). Therefore, section 2 can be correlated from the Serpukhovian to the lowermost Permian although a lower-middle Pennsylvanian interval is not clearly recognized (Fig. 4).

\section{Lithofacies types}

\section{Green algal grainstone}

Description Green algal grainstone is characterized by abundant Pseudogyroporella sp. and Beresella sp. that are commonly associated with foraminifera (Triticites, staffellids, schwagerinids, Rauserites) and echinoderms 
(Fig. 7). Gastropods, Tubiphytes sp., fenestrate bryozoans, brachiopods, phylloid algae and worm tubes (Thartharella sp.) represent minor components. Peloids, coated grains, mud clasts as well as grain aggregates are common. Grains range in size from 0.2 to $7 \mathrm{~mm}$. Intergranular porosity is infilled by radiaxial-fibrous, drusy and blocky calcite cements. Locally, the green algal grainstone lithofacies is poorly washed, containing both micritic matrix and calcite cement.

Interpretation The predominance of the grainstone texture suggests high-energy environments. The abundance of green algae points to a depositional setting within the photic zone, from a lagoonal environment to shallow shoals (Mamet 1991). However, the association of green algae, Tubiphytes sp. and phylloid algae strongly suggest open-marine conditions (e.g. Mamet 1991; Dawson and Racey 1993). This interpretation is supported by the occurrence of suspension feeders (bryozoans, brachiopods and echinoderms) which require well-oxygenated waters and normal salinity (Wilson 1975).

\section{Coated-grain grainstone}

Description Coated-grain grainstone is characterized by abundant subspherical to ellipsoid cortoids, up to $50 \%$, ranging in size from 0.2 to $2 \mathrm{~mm}$ (Fig. 8). The coated biogenic components include phylloid algae, echinoderms, fenestrate bryozoans, gastropods, bivalves, Tubiphytes sp., the green algae Epimastopora sp. and Beresella sp., foraminifera (Schwageriniformis, Rauserites) and brachiopods. These bioclasts are associated with peloids and scarce mud clasts $(<2 \mathrm{~mm}$ in diameter). The cortex of cortoids consists of a thin non-laminated micrite envelope. The lamina surface is smooth. Radiaxial-fibrous, blocky and drusy calcite cements are common.

Interpretation Cortoids resulted from destructive micritization process linked to the activity of microboring organisms. These microborers, light dependent, are commonly interpreted as an indicator of shallow-marine conditions (<20 m; Swinchatt 1969; Lees and Miller 1985; Aretz and Herbig 2008). Additionally, the occurrence of green algae points to a setting within the photic zone. In Spain, Epimastopora, associated with other dasycladaceans and oncoids, is abundant in outer-shelf facies and occurs commonly in shallow and high-energy environments (Della Porta et al. 2002). Therefore, shallow and agitated waters, located above the FWWB in the photic zone, such as those prevailing in shoals (e.g. Kumpan et al. 2014; Udchachon et al. 2014; Erfani et al. 2016), are inferred.

\section{Bioclastic packstone, grainstone, floatstone, rudstone}

Description Bioclastic packstone, grainstone, floatstone and rudstone, locally burrowed, are characterized by the abundance of diverse angular fragments of skeletal components, poorly sorted, ranging in size from 0.1 to $5 \mathrm{~mm}$ (Fig. 9). Most of the biogenic components consist of fenestrate and fistuloporid bryozoans, Tubiphytes sp., foraminifera (Schwageriniformis, staffellids, schwagerinids, Rauserites, Ozawainella, Schubertella, Fusiella) and brachiopods associated to solitary and colonial rugose corals, echinoderms, bivalves, phylloid algae (unspecified), green algae (Beresella sp., Pseudogyroporella sp., Gyroporella sp., Epimastoporella sp., Epimastopora sp., Diplopora sp.?), calcimicrobes (Archeolithoporella sp., Garwoodia sp.), gastropods and worm tubes (Thartharella sp.). Locally, some intervals consist of densely packed phylloid algal thalli, colonial and solitary corals or brachiopod shells. Scarce peloids, mud clasts and coated grains occur. Intergranular porosity is infilled by fibrous, radiaxial-fibrous, drusy, blocky and locally dog tooth cements.

Interpretation Autochthonous bioclastic packstone, grainstone, floatstone and rudstone are characterized by poorly sorted whole fossils and fragments, which suggest in situ components. The occurrence of burrows suggests shallow lagoon with open marine circulation, deep shelf or mid and outer ramp settings (Henderson et al. 1999; Flügel 2010). However, the association of dasyclad green algae, phylloid algae and calcimicrobes points to a depositional setting within the photic zone (Mamet 1991). In addition, the occurrence of suspension feeders (e.g. bryozoans, brachiopods and corals) which require well-oxygenated waters and normal salinity (Wilson 1975) suggest open marine depositional environment. All these elements allow to constrain the depositional environment to a reef flank setting (Flügel 2010), in a shallow subtidal environment, located in the photic zone.

Allochthonous bioclastic packstone, grainstone, floatstone and rudstone is characterized by abraded fossil fragments, associated with mud clasts. Grains occur in chaotic order or present grading texture. Skeletal fragments consist of reef-derived organisms, likely transported down by turbidites, deposited in forereef position, reef slope, toe-ofslope, and basinal settings (Flügel 2010).

\section{Microbial boundstone}

Description Microbial boundstone is characterized by stromatolitic internal structures and wrinkle structures on the weathered surface, which is composed of abundant marine cement and encrusting microbial micrite. Three microscopic structures of the microbial boundstone have been identified, 

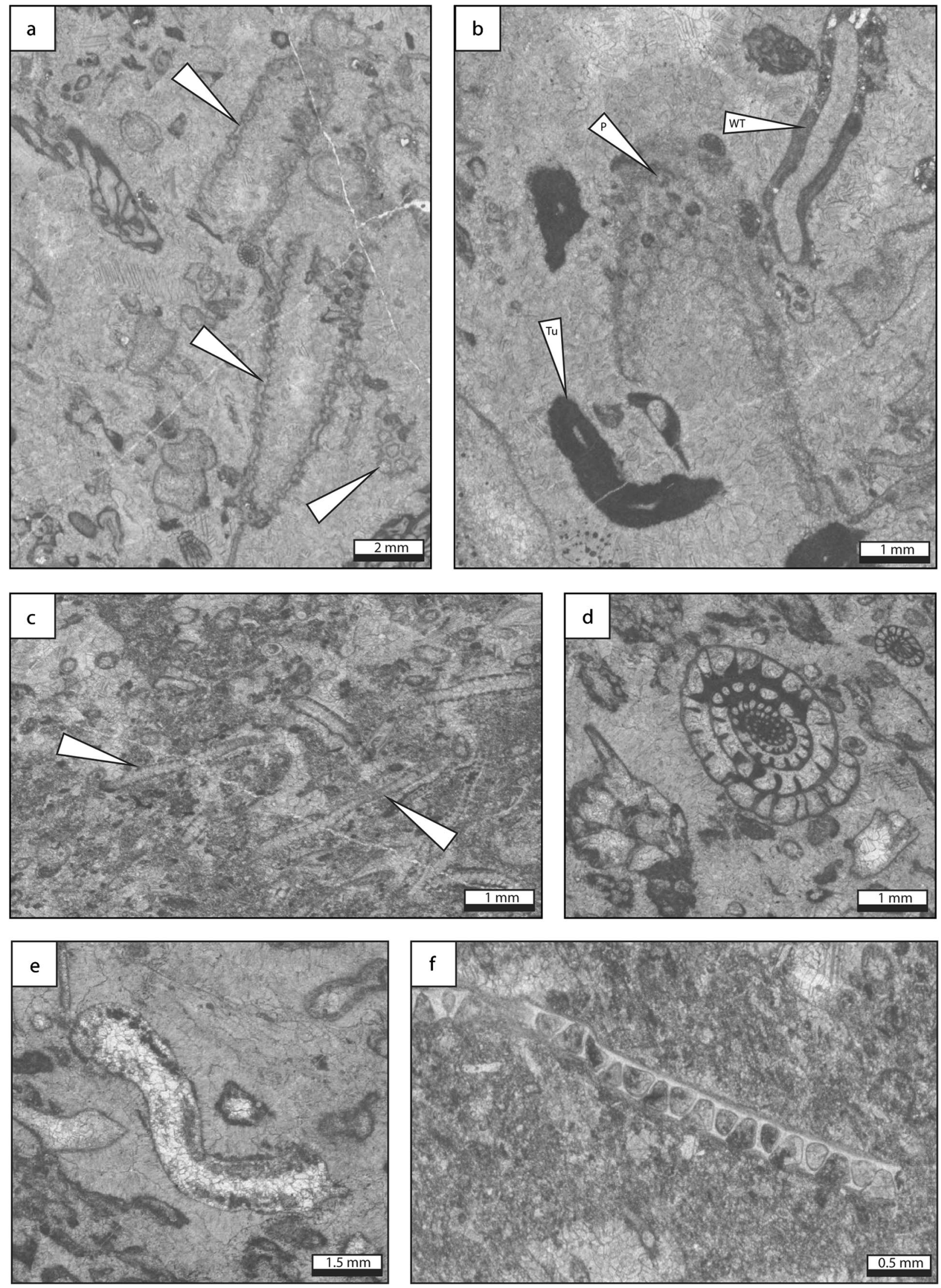
4Fig.7 Green algal grainstone lithofacies type, which is the most updip and shallow-water facies type. a Dasycladacean green alga Pseudogyroporella-rich grainstone. b Green algal fragment with associated Tubiphytes and a worm tube. The cement consists of radiaxial fibrous and late blocky cement. c Poorly-washed grainstone with common Beresella algal fragments. d Oblique specimen of the fusuline Schwageriniformis sp. in bioclastic grainstone. e Phylloid algal fragment (center). f Fenestrate bryozoan fragment in finegrained skeletal-peloidal packstone matrix. P: Pseudogyroporella sp., Tu: Tubiphytes sp., WT worm tube

including encrusting, laminar, and grid-shaped microbial fabrics (Fig. 10, Huang et al. 2019). Abundant microbial carbonate (e.g. thrombolitic textures, microstromatolites, and microbial ooids) and calcimicrobes (e.g. Girvanella, Ortonella, and Wetheredella-like) occur in the deposits between microbial boundstone and the coral Ivanovia (Huang et al. 2019). Subordinate contributors include corals, crinoids, bryozoans, algae, and sponges.

Interpretation Microbial boundstone, in association with the coral Ivanovia, form the Zhongxinzhai mound (Houchang town, Guizhou). The association of microbial boundstone with numerous calcimicrobes, algae, corals and bryozoans, may indicate that the microbial boundstone was formed in the euphotic zone, with normal salinity condition (Gong et al. 2007a; Zhang et al. 2009; Huang et al. 2019). Ivanovia encrusts hard substrates and favors shallow, clear, highenergy environments (Zhang et al. 2009), which display an alternating encrusting growth pattern with the microbial boundstone, suggesting a shallow and clear water.

\section{Phylloid green algal boundstone}

Description Phylloid algae form a dense framework with shelter cavities filled by marine cement (radiaxial-fibrous, drusy and blocky) and peloidal micrite (Fig. 11a). The undulate leaf-like algal thalli are commonly recrystallized. Additional organisms include foraminifera (Schwageriniformis), echinoderms, the green algae Epimastopora sp. and Pseudogyroporella sp., bryozoans, Tubiphytes sp., worm tubes (Thartharella sp.) and bivalves along with scarce mud clasts. The peloidal matrix is composed of dense, clotted or partly laminated micrite.

Interpretation Phylloid algae are commonly reported as growing in shallow waters, under moderate energy conditions, within the photic zone (e.g. Beauchamp et al. 1989; Wahlman 2002; Gong et al. 2007a, b). This interpretation is supported by the occurrence of dasyclad green algae and Tubiphytes sp., commonly growing in shallow-waters (Mamet 1991). The high diversity biotic association including brachiopods, bryozoans, and foraminifera, attest for open marine conditions and well-oxygenated waters (Oertli
1964; Wilson 1975). Phylloid algal mounds are extensively documented in the literature as growing in relatively shallow subtidal settings (e.g. Toomey et al. 1977; Soreghan and Giles 1999; Samankassou and West 2002).

\section{Ivanovia cf. manchurica boundstone}

Description In Houchang, the encrusting Ivanovia cf. manchurica (Fig. 11b) is considered as an aphroid coral (e.g. Zhang et al. 2009; Gong et al. 2012). Within the Zhongxinzhai mound, Ivanovia cf. manchurica measures about $1.2 \mathrm{~cm}$ in diameter. Ivanovia boundstone forms massive-shaped domes, reaching $2 \mathrm{~m}$ lateral extension and $0.3-0.7 \mathrm{~m}$ thickness. The matrix consists of bioclastic grainstone, mainly composed of crinoid stems.

Interpretation The grainstone texture suggests agitated waters. In addition, Ivanovia are common in intertidal and shallow subtidal environments, in warm and clear marine environment within the photic zone (Taylor and Wilson 2003; Zhang et al. 2009). Therefore, the Ivanovia cf manchurica boundstone formed likely in shallow-water and high energy depositional environment, above the FWWB.

\section{Branching coral boundstone}

Description Branching colonial corals (Fomitchevella sp.) form a distinct framework, occurring commonly in their original up-right position. Branching corallites reach a maximum of $7 \mathrm{~cm}$ in diameter and $60 \mathrm{~cm}$ height (Fig. 11c). The matrix consists of micrite, including fragments of algae (undetermined), brachiopods (Choristites, Martinia) and crinoids, and few fusulines (Triticites, Schwagerina, Gong et al. 2004; Gong et al. 2012).

Interpretation Chappell (1980) suggested that branching corals appear as moderately light-dependent, living in calm waters under high sediment influx, in subtidal settings. Scrutton (1999) suggested that fasciculate growth forms were favored by rapid sedimentation rates and less frequent scouring event. The enclosing sediments composed of micrite with scarce skeletal debris (algae, crinoids, brachiopods) confirm low-energy conditions (Scrutton 1999). Therefore, the branching coral boundstone is interpreted as growing in a low energy depositional environment, below the FWWB.

\section{Burrowed bioclastic wackestone}

Description Burrowed bioclastic wackestone is composed of bioclast fragments which include phylloid algae, bryozoans, foraminifera, echinoderms, bivalves, brachiopod spines, Tubiphytes sp. and Donezella sp. (Fig. 12a). Peloids, mud 

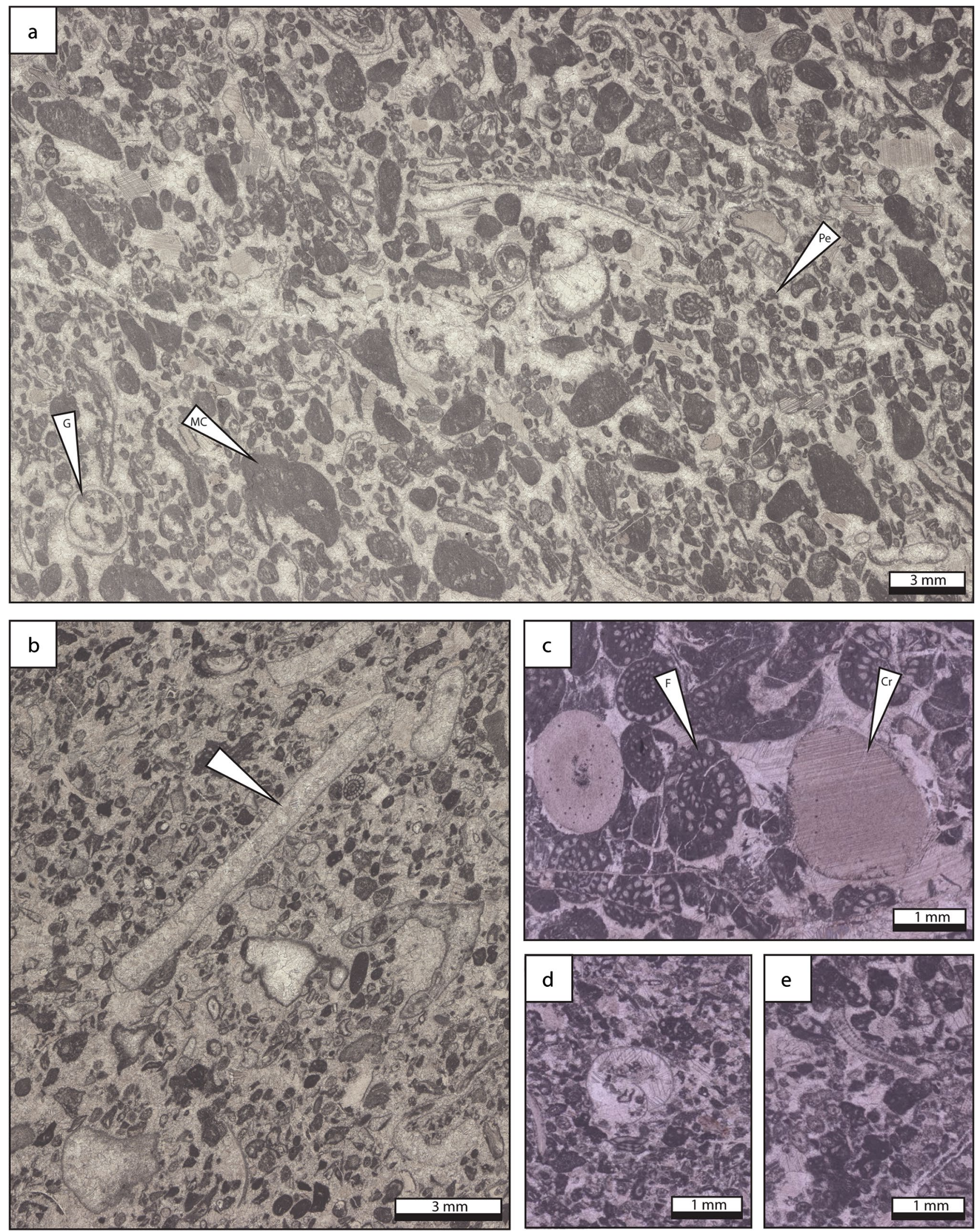
4Fig. 8 Coated grain grainstone lithofacies type which represents an updip shallow-water, high energy paleoenvironment. a Grainstone composed of molluscan bioclasts, including small gastropods, and darkened micritized and coated bioclasts and peloids. b Fine-grained peloidal grainstone matrix with sparse coarser-grained mollusc and algal fragments. c Coarse-grained fusuline-crinoid grainstone. d Fine-grained peloidal grainstone with coarser-grained gastropod shell fragment. e Peloidal-bioclastic grainstone with sparse Beresella algal fragments. $\mathrm{Cr}$ crinoid, $\mathrm{F}$ foraminifera, $G$ gastropod, $M C$ micritized grain, $P e$ peloid

clasts and coated grains occur scarcely. Vugs are filled by drusy and blocky calcite cements.

Interpretation The burrowed bioclastic wackestone could have originated as either lagoonal deposits or as basinal background sedimentation, deposited below the FWWB. The occurrence of burrows suggests shallow lagoon with open marine circulation, deep shelf or mid and outer ramp settings (Henderson et al. 1999; Flügel 2010). The lack of light-dependent dasyclad algae allows to restrain the depositional environment to the dysphotic zone (Mamet 1991). Therefore, the origin of the burrowed skeletal wackestone is interpreted as in situ sedimentation, deposited in a lowenergy environment below the FWWB and certainly below the SWB (e.g. Casier et al. 2004).

\section{Microbioclastic peloidal packstone and grainstone.}

Description Microbioclastic peloidal packstone and grainstone is composed of detrital silt-sized calcite particles $(2-63 \mu \mathrm{m})$, including peloids, litho- and bioclast fragments (Fig. 12b). The biogenic components consist of disarticulated crinoids, shell debris and scarce ostracods. Millimeterscale ripple cross-lamination and laminae occur.

Interpretation Microbioclastic peloidal packstone and grainstone are produced by abrasion and bioerosion processes. The low-angle cross-stratification suggests oscillatory flows, likely induced by storms, or turbidity currents (e.g. Kim and Lee 1996; Seguret et al. 2001; Woo and Chough 2007; Chen et al. 2011; Merhabi et al. 2015). Microbioclastic peloidal packstone and grainstone occur commonly in toe-of-slope, outer ramp and basinal environments (Flügel 2010).

\section{Fine-grained burrowed wackestone and packstone}

Description Dark-colored fine-grained burrowed wackestone and packstone are composed of microfossils, including sponge spicules, shell debris and echinoderm fragments (Fig. 12c, d). Bioclasts are scattered within a dense and strongly burrowed mud matrix. Locally, skeletal fragments are densely packed or sparsely distributed due to the intense burrowing.
Interpretation The skeletal assemblage, composed of finegrained benthic biodetritus including spicule sponges, are common in deep-marine environments, both in slope and basinal settings (Wiedenmayer 1980; Jach 2001). The abundance of burrows supports this statement, occurring commonly in the deep shelf, mid and outer ramp settings (Henderson et al. 1999; Flügel 2010). Therefore, the fine-grained burrowed wackestone and packstone were deposited in outer ramp, deep shelf, and basinal settings with aerobic to possibly dysaerobic bottom conditions (Flügel 2010).

\section{Lithofacies successions}

\section{Shallow-water section (section 1)}

The lithofacies succession of section 1 suggests shallowwater depositional environments (Fig. 13). The rock succession is dominated by thick limestone beds ( $>2 \mathrm{~m}$ ), dated as Kasimovian to Gzhelian in age. Lithofacies include coated grain grainstone, green algal grainstone, bioclastic packstone, grainstone and rudstone, bioclastic wackestone and floatstone, phylloid algal boundstone, microbial boundstone and burrowed wackestone. From 44 to $59 \mathrm{~m}$, a microbial mound (15 m high, $200 \mathrm{~m}$ wide, Fig. 14) was identified, with the secondary contribution of phylloid algae and the coral Ivanovia. The substrate consists of bioclastic wackestone and packstone composed of various organisms including microbialite debris, crinoids, foraminifera, bryozoans, brachiopods, gastropods and algae, along with peloids and coated grains. The base of the mound is characterized by phylloid algal bafflestone ( $2 \mathrm{~m}$ thick and $8 \mathrm{~m}$ wide) and the core is built by microbial boundstone and the coral Ivanovia. The grain assemblage suggests a subtidal paleoenvironment, deposited in shallow-waters, within the photic zone (Huang et al. 2019).

\section{Deep-water section (section 2)}

The lithofacies succession of section 2 is dominated by deepwater deposits (Fig. 15) ranging in age from the Serpukhovian to Early Permian. The Serpukhovian is characterized by the deposition of chert belts (Fig. 15b), fine-grained burrowed wackestone and packstone, and microbioclastic peloidal packstone and grainstone, exhibiting commonly millimeter-scale ripple cross-lamination and laminae (Fig. 15c). During the latest Mississippian-earliest Pennsylvanian, the sediment succession was dolomitized, likely due to the global sea-level fall (Ross and Ross 1987; Rygel et al. 2008). Then, from the Kasimovian?-Early Permian (Asselian), the sedimentary succession is dominated by fine-grained burrowed wackestone and packstone, microbioclastic peloidal packstone and grainstone ( $<1 \mathrm{~m}$ thick), associated with thin 

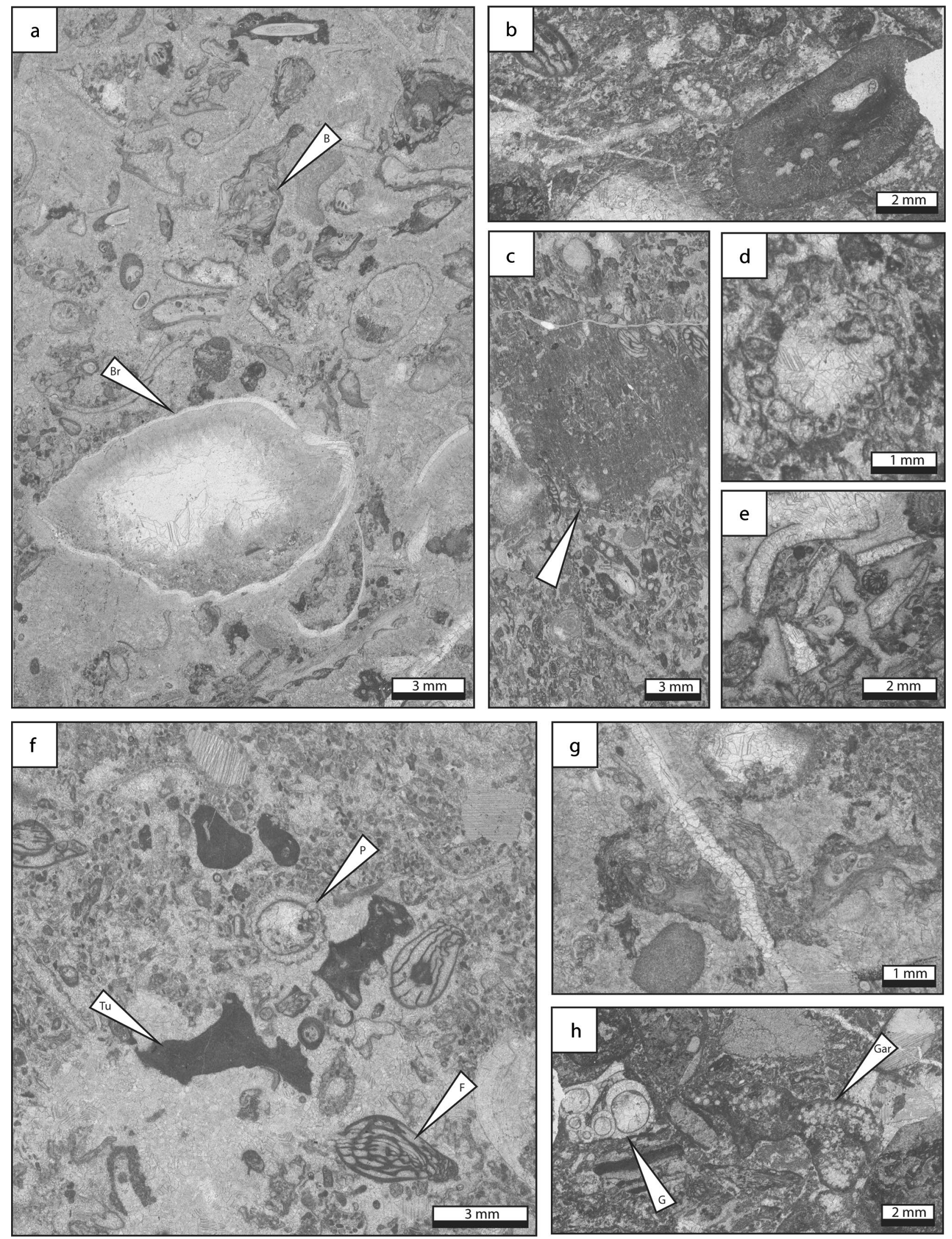
4Fig. 9 Bioclastic grainstone, packstone, rudstone and floatstone lithofacies type. The lithofacies is composed of diverse bioclasts, including a bryozoans, brachiopods, molluscs, b, f Tubiphytes, $\mathbf{c}$ mud-filled burrows in foraminifer-rich packstone matrix, d Gyroporella sp., e phylloid algae fragments, foraminifera, Pseudogyroporella sp., g fistuliporid bryozoans, h Garwoodia sp. and gastropods. $B$ bryozoan, $B r$ brachiopod, $F$ foraminifera, $G$ gastropod, Gar Garwoodia sp., $P$ Pseudogyroporella, Tu Tubiphytes $\mathrm{sp}$

marls (few centimeters) and allochthonous bioclastic packstone, grainstone and rudstone beds, commonly laminated (planar lamination; Fig. 15a). During the late Early Permian (Sakmarian), lithofacies are composed of in situ bioclastic packstone, grainstone and rudstone layers.

\section{Bianping coral reef section}

The Bianping coral reef section (Fig. 16) was described by Gong et al. (2004). The reef substrate is composed of bioclastic grainstone, including foraminifera (Triticites, Textularia), brachiopods (Martinia) and crinoids. The lower part of the reef (10 m thick) consists of three patch-reefs, built by phylloid algae, calcimicrobes and the coral Ivanovia cf manchurica, respectively. These patch-reefs are overlain by bioclastic packstone and grainstone, prior to be capped by a brachiopod-rich packstone layer ( $8 \mathrm{~m}$ thick), dominated by Choristites brachiopods, foraminifera (Triticites, Textularia) and corals (Fomitchevella). Above, the coral reef core (37 m thick) is dominated by the Fomitchevella branching colonial corals. Between the coral framework occur bioclast packstone deposits, composed of fusulines (Triticites, Schwagerina), brachiopods (Choristites, Martinia) and crinoids. The basal part of the reef $(5 \mathrm{~m})$ is composed of isolated coral patch-reef frameworks with interstitial packstones of densely packed bioclasts of crinoids, fusulines and algal

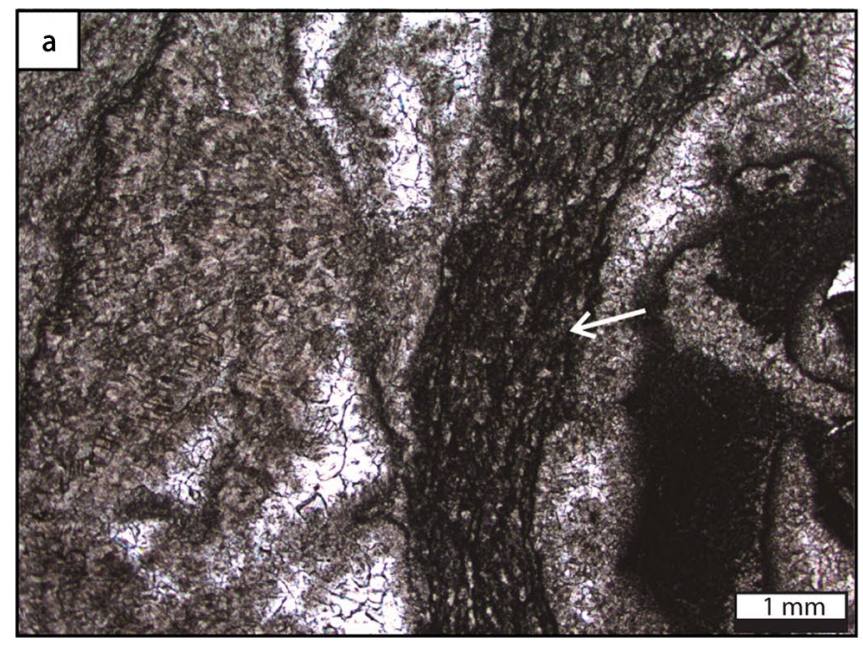

Fig. 10 Microbial boundstone lithofacies type, built by undetermined algal-like microbial fabrics. a Encrusting form (white arrow), with the fuzzy structure encrusting the thrombolitic clasts. b Laminar debris. Above, branching corals built a large and massive framework (15 m thick), capped by a bioclastic packstone layer (13 m thick) composed of fusulines and brachiopods. The upper $4 \mathrm{~m}$ of the reef is composed of massive coral framestone. Between the coral framework occur bioclastic packstone deposits. Finally, the reef cover consists of bioclastic packstone and grainstone, including fusulines (Triticites, Schwagerina), brachiopods (Choristites, Squamularia) and crinoids.

\section{Interpretations}

\section{Depositional environment of the Bianping coral reef}

The depositional environment of the Bianping coral reef is currently not well constrained. However, its lithofacies succession provides precious information about the depositional environment (Fig. 16). The reef substrate, composed of bioclastic grainstone, including foraminifera brachiopods and crinoids, is indicative of a high-energy depositional environment, located above the FWWB. Then, the biotic assemblage of the lower part of the reef (calcimicrobes, Ivanovia cf. manchurica and phylloid algae) suggests shallow subtidal settings, deposited around the FWWB within the photic zone. Conversely, the reef core composed of branching coral framestone (Fomitchevella, Fig. 11c) and bioclastic packstone indicates a slightly lower-energy and deeper environment, deposited below the FWWB. The reef cover, composed of bioclastic packstone and grainstone suggestive of a shallower environment, deposited in more agitated waters, around the FWWB.

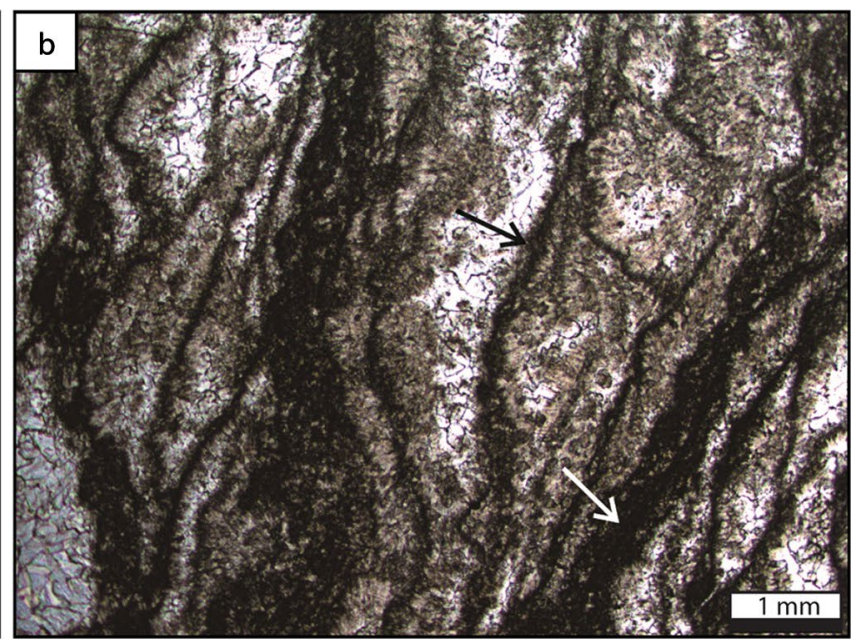

(white arrow) and grid-shaped (black arrow) microbial microfabrics. From Huang et al. (2019) 

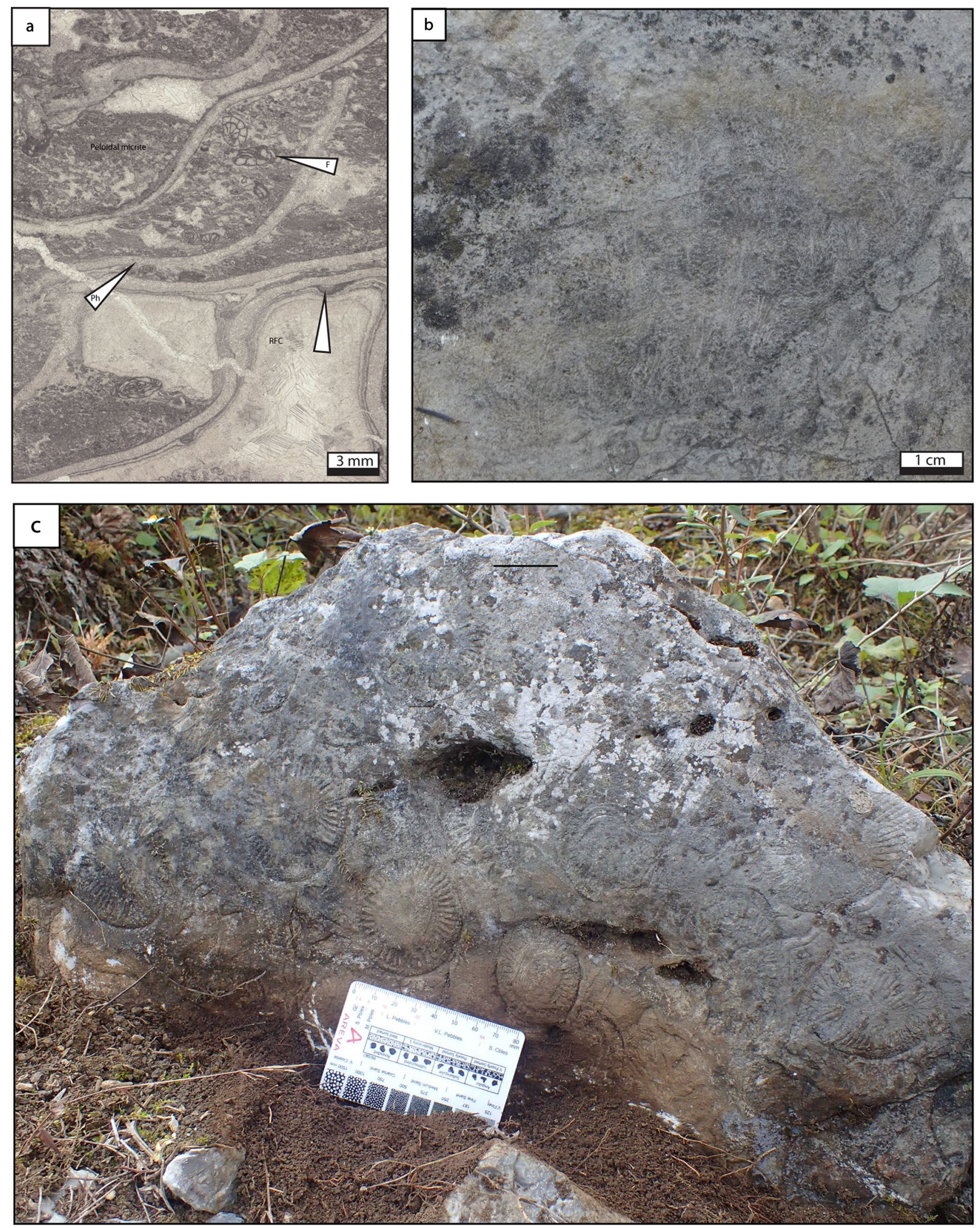
4Fig. 11 Phylloid algal and coral boundstone lithofacies types. a Phylloid algal boundstone. Pores are filled by fine-grained peloidal packstone and marine radiaxial calcite cement. Algal thalli are draped by conspicuous marine cement or encrusted by microbialite and Tubiphytes prior to the precipitation of marine cement in interstitial space. Matrix contains common fusuline foraminifera. b Ivanovia coral. c Branching rugose corals (Fomitchevella) formed large colonies $(>50 \mathrm{~cm})$, preserved in their original up-right position. $F$ foraminifera, $P h$ phylloid algae, $R F C$ radiaxial fibrous cement

\section{Bianping coral reef: a world exception}

At tropical to subtropical latitudes, Bashkirian-Moscovian shelf to shelf-margin bionconstructions were dominated by mounds and banks constructed by calcareous algae (e.g. West 1988), Chaetetes sponges (e.g. Connolly et al. 1989; Hamilton 2014) and microbialites (e.g. Samankassou 2001; Della Porta et al. 2003; Bahamonde et al. 2007). In the Late Moscovian, the composition of tropical shallow-water organic buildups changed significantly with the radiation of erect phylloid algae, which became the most dominant reef-builder throughout Late Pennsylvanian and earliest Permian (e.g. Heckel and Cocke 1969; Toomey 1991; Gong et al. 2007a, b; Samankassou and West 2002; Wahlman 2002). In slightly deeper water settings, small buildups were constructed by erect bryozoans, crinoids, and calcareous sponges that were encrusted by laminar red algae (e.g. Archaeolithophyllum), fistuliporid bryozoans and Tubiphytes (e.g. Toomey 1979; Schatzinger 1983; Wahlman 2002).

However, scarce Pennsylvanian coralliferous bioconstructions were also reported worldwide (Table 3).

1. In Oklahoma (US), Late Viséan-Early Bashkirian Petalaxis coral patch reefs were reported in shallow subtital to intertidal settings (Sutherland and Henry 1977).

2. In Kazakhstan, Middle Viséan-Early Bashkirian coralcrinoid-bryozoan-algal-Tubiphytes reefs were discovered at the platform margin (Cook et al. 1994).

3. In Japan, the Akiyoshi Limestone Group represents a large reef complex that developed on a volcanic seamount. During the Viséan-Early Bashkirian, the initiation of the Akiyoshi reef complex was led by the proliferation of corals, bryozoans and crinoids (Ota 1968; Nakazawa 1997). During the Bashkirian-Moscovian, the Akiyoshi reef cores included chaetetids, calcareous algae, bryozoans, and tabulate and rugose corals (Nagai 1985; Sugiyama and Nagai 1990, 1994). Sugiyama and Nagai $(1990,1994)$ interpreted the Akiyoshi buildup as a high energy walled-reef complex, analogous to modern coral oceanic atolls.

4. In Ukraine (Donets Basin), Bashkirian and Early Moscovian coral and coral-chaetetid biostromes $(<6 \mathrm{~m}$ thick) were reported in shallow waters (Ogar 2012). In detail, the Pashenna bioherm ( $>3 \mathrm{~m}$ thick, section) is dominated by chaetetids and corals (Ivanovia). The Holubivka bioherm ( $>3 \mathrm{~m}$ thick) is composed of brachiopods, chaetetids, solitary rugose corals (Yuanophylloides), massive colonial corals (Petalaxis) and stromatolites. The Karahuz bioherm (6 m thick) includes microbialites, foraminifera, worm tubes, crinoids, solitary rugose corals (Axolithophyllum, Yuanophylloides and Monophyllum), tabulate corals (Cladochonus), and bryozoans (6 $\mathrm{m}$ thick). The Maryivka biostromes are composed of corals, calcareous algae, crinoids, brachiopods and foraminifera.

5. In Spain, Dingle et al. (1993) described BashkirianMoscovian coral-Chaetetes buildups (few centimeters thick), dominated by Chaetetes, solitary rugose corals (Caninia) and tabulate corals (Multithecopora). These buildups developed in shallow waters, high-energy environments (packstone-grainstone facies). Bahamonde et al. $(2015,2017)$ reported Moscovian coral bioherms and biostromes (10's-cm-thick) composed of undetermined branching rugose coral colonies associated with cerioid colonies, solitary rugose corals, auloporid corals and Chaetetes. These bioconstructions were deposited in moderate-energy and relatively shallow-water environments, below the FWWB.

6. In Nevada (US), Moscovian Chaetetes reefs were discovered. The main reef-builders are Chaetetes associated to fusulines, algae (Ivanovia, Donezella, Dvinella), rugose corals (Caninia, Amandophyllum, Caniniostrotion, Tschussovskenia), tabulate corals (Syringopora, Multithecopora) and bryozoans (Wilson 1963; Nelson and Langenheim 1980; Gong et al. 2012).

7. In the Moscow Basin, Late Moscovian coral biostromes and bioherms were described, dominated by rugose corals (Ivanovia, Petalaxis) and chaetetids (Podolskian and Myachkovian Horizons; Ogar 2012).

8. In Austria-Italy (Carnic Alps), Kasimovian coral mounds (50 cm thick) were identified (Samankassou 2003), composed of auloporid corals (Multithecopora syrinx), associated to sponge spicules (?), worm tube structures, shell fragments, foraminifera, ostracods, and chaetetid sponges. Coral mounds grew in a low-energy depositional environment.

All of these Pennsylvanian coralliferous bioconstructions were dated from Bashkirian-Kasimovian, with a Gzhelian "reefless lag time", and grew in environments ranging from shallow-waters (above the FWWB) to the low-energy environment (below the FWWB). The reefsize remains small, measuring 10 's centimeter to meter thick $(<6 \mathrm{~m})$, except in Japan (large atoll). The reefal assemblages were commonly composed of corals, chaetetids, calcareous algae, foraminifera, crinoids, molluscs, 

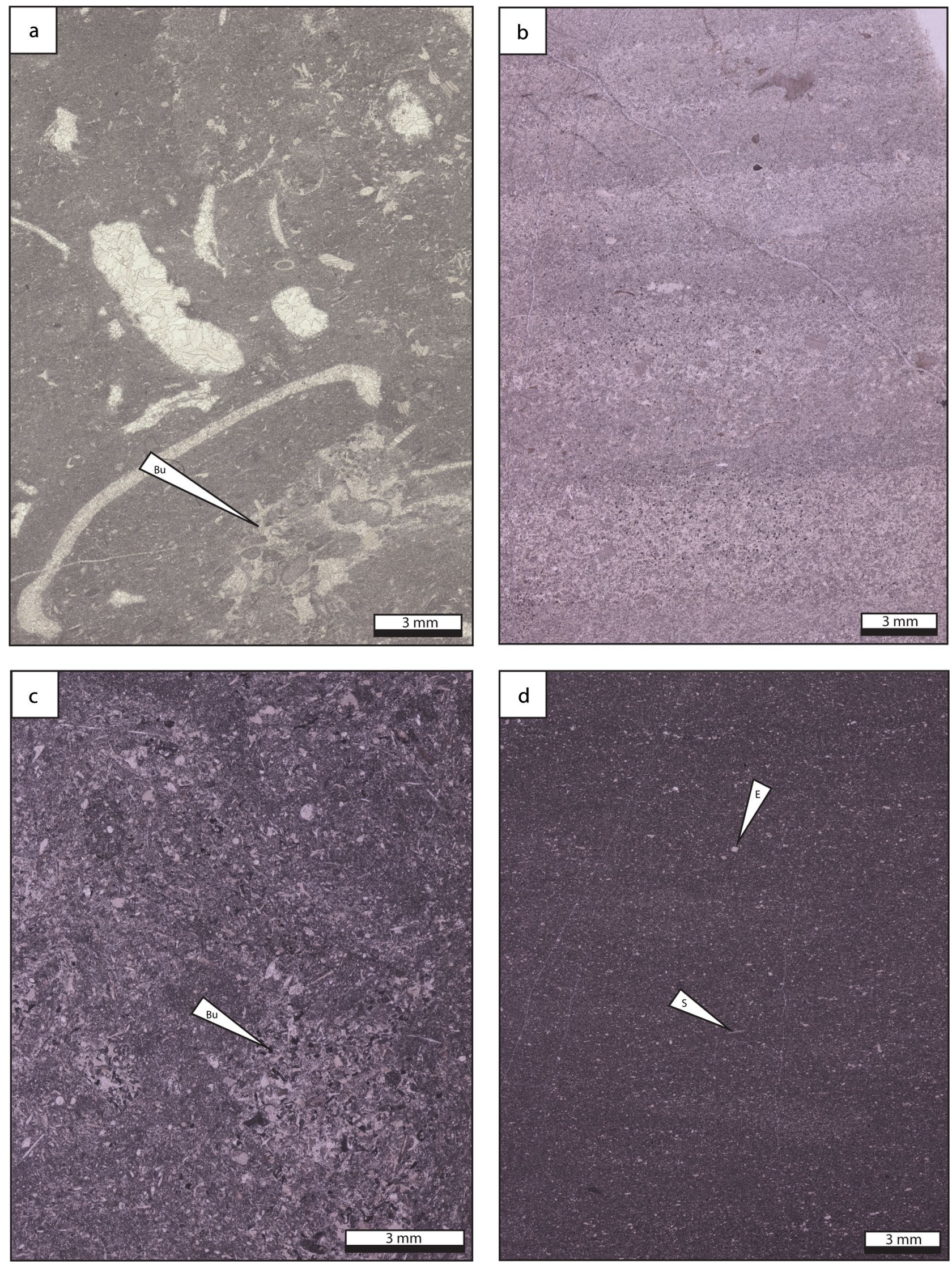

\section{d}
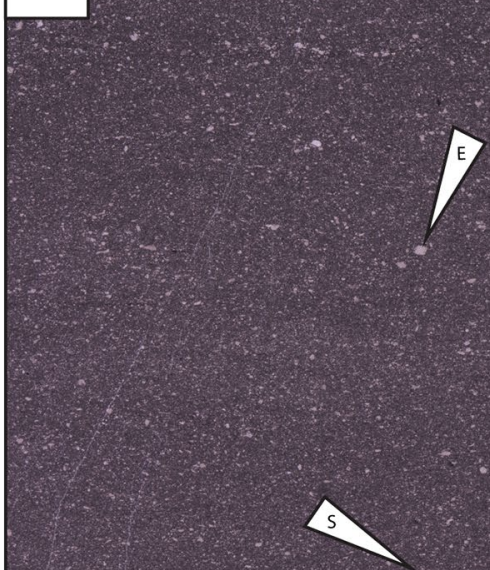
4Fig. 12 Burrowed bioclastic wackestone, microbioclastic peloidal packstone-grainstone and fine-grained burrowed wackestone-packstone lithofacies types, which represent a deep-water, low energy paleoenvironment. a Burrowed bioclastic wackestone. Biogenic components consist of foraminifera, debris of echinoderms and phylloid algae. Locally, scarce peloids occur. b Laminated microbioclastic peloidal packstone and grainstone with fine peloids and exhibiting mm-scale layering. c Fine-grained burrowed wackestone and packstone composed of small-sized fossil fragments, scattered within a dark and strongly burrowed matrix. Burrows are infilled with microbioclastic peloidal packstone and grainstone sediments. d Finegrained burrowed wackestone. Matrix consist of dark grey micrite. Bioclasts include small echinoderm fragments and spicule sponges. $B u$ burrow, $E$ echinoderm, $S$ spicule sponge

bryozoans, associated locally to worm tubes, microbialites, stromatolites and Tubiphytes.

Consequently, the Bianping reef in Houchang, southern China (Zhang et al. 2010; Gong et al. 2012), adds to the current knowledge a new Late Pennsylvanian reef type lacking any analogs in age (Gzhelian), size (80-100 m thick), and biodiversity (Fomitchevella, phylloid algae, Ivanovia, Antheria, microbialites, brachiopods, fusulines, crinoids, algae, bryozoans, Tubiphytes).

\section{Platform model}

The Houchang area is located at the border of a shelfal depression, inherited by pre-Carboniferous tectonic deformations (Tsien et al. 1988; Shen 2002). The Kasimovian-Gzhelian shallow-water limestones are composed of coated-grain grainstone and green algal grainstone lithofacies, deposited in shoals and/or above the FWWB. Bioclastic packstone, grainstone and rudstone deposited around the FWWB. The lack of siliciclastic deposits points to a low sediment influx, possibly due to a far distance from the Yangtze Craton. In shallow-waters, during the Kasimovian-Gzhelian, the persistence of stenohaline organisms such as bryozoans, brachiopods and foraminifera, tends to reflect normal salinity conditions (Oertli 1964; Flügel 2010). However, during the Kasimovian, the abundance of staffellids (Fig. 13), commonly considered to have wider environmental tolerance (Vachard et al. 2010), associated to sporadic schwagerinids documents possibly a time interval with slightly higher salinity, related to a restricted environment and/or semi-restricted conditions, likely controlled by sea-level fluctuations. Conversely, the Late Kasimovian-Gzhelian deep-water rocks are composed of microbioclastic peloidal packstone and grainstone, in situ fine-grained burrowed wackestone and packstone deposited in a low energy depositional environment, marls and thin allochthonous bioclastic packstone, grainstone, floatstone and rudstone layers (calciturbidites). The scarce and thin calciturbidite layers ( $<1 \mathrm{~m}$ thick), indicate a starved basin, with a low sediment export from platform to adjacent basins. The transition from shallow-water (section 1) to basinal environments (section 2) points to a ramp, possibly distally steepened, or a slope (Fig. 17). From the Gzhelian to Early Permian (Asselian-Sakmarian), the deepwater rock succession presents a shallowing-upward sequence, dominated by the deposition of bioclastic packstone, grainstone and rudstone layers, which seems to indicate that the shelfal depression gradually became infilled, certainly due to the global sea-level fall (Early Permian glaciation; Fielding et al. 2008a; Rygel et al. 2008).

Within the Timan-Pechora Basin (Northern Russia), elongate seafloor structures are reported during the Pennsylvanian-Early Permian, consisting of narrow structural highs separated by broad depressions (Wahlman and Konovalova 2002). On the top and flanks of structural highs, light-colored and commonly fusuline-rich bioclastic grainstone-packstone shoals and Palaeoaplysina bioherms were deposited. Conversely, in the deeper-water shelfal depression, dark-colored argillaceous fenestrate bryozoan-crinoidal wackestone and packstone were accumulated. In the distal part of the shelf, near the western margin of the Ural Through, a carbonate bank grew on a slope or deep-ramp paleogeographic highs. The surrounding deep-water seafloor facies consist of dark-grey cephalopod-bearing marls, shales and siltstones (Wahlman and Konovalova 2002).

The sedimentary depositional systems of the Dian-Qian-Gui Basin (southern China) and Timan-Pechora Basin (Northern Russia) appear to be similar in terms of lithofacies and structures. However, the reported respective reefs differ in composition. In southern China, shallow-water reefs are composed of calcimicrobes (Huang et al. 2019), red algae (Tan 1991; Yao and Wang 2016), phylloid algae (Gong et al. 2007a, b), Tubiphytes (Chang et al. 2008; Guan et al. 2010; Yao and Wang 2016) and corals (Zhang et al. 2010; Gong et al. 2012), whereas in the Timan-Pechora Basin bioherms are composed of Palaeoaplysina and bryozoan-Tubiphytes (Wahlman and Konovalova 2002). The bioherm compositions can be explained by the paleolatitudes: southern China was located in subequatorial position $\left(15^{\circ} \mathrm{S}\right)$, whereas Northern Russia was located in subtropical to temperate paleolatitudes $\left(20-30^{\circ} \mathrm{N}\right.$; Webb 2002). Therefore, the Dian-Qian-Gui Basin (southern China) can be considered as a warm-water counterpart of the temperate Timan-Pechora Basin (Northern Russia).

\section{Discussion}

The scarcity of Pennsylvanian coral reefs documents unfavorable conditions globally for their development. However, the exceptional occurrence of the Bianping coral reef, reported in southern China, reveals specific settings favoring the development of coral communities. This occurrence raises several questions: How do environmental conditions 
Fig. 13 Lithofacies successions and paleoenvironments, from section 1 (Zongxinzhai), showing distributions of corals and staffellid foraminifers. The abundance of staffellids in the lower section indicate shallowwater, possibly restricted marine paleoenvironments, and the overlying coral-rich facies indicates a significant sea level rise and a change to a deeper-water shelf margin setting

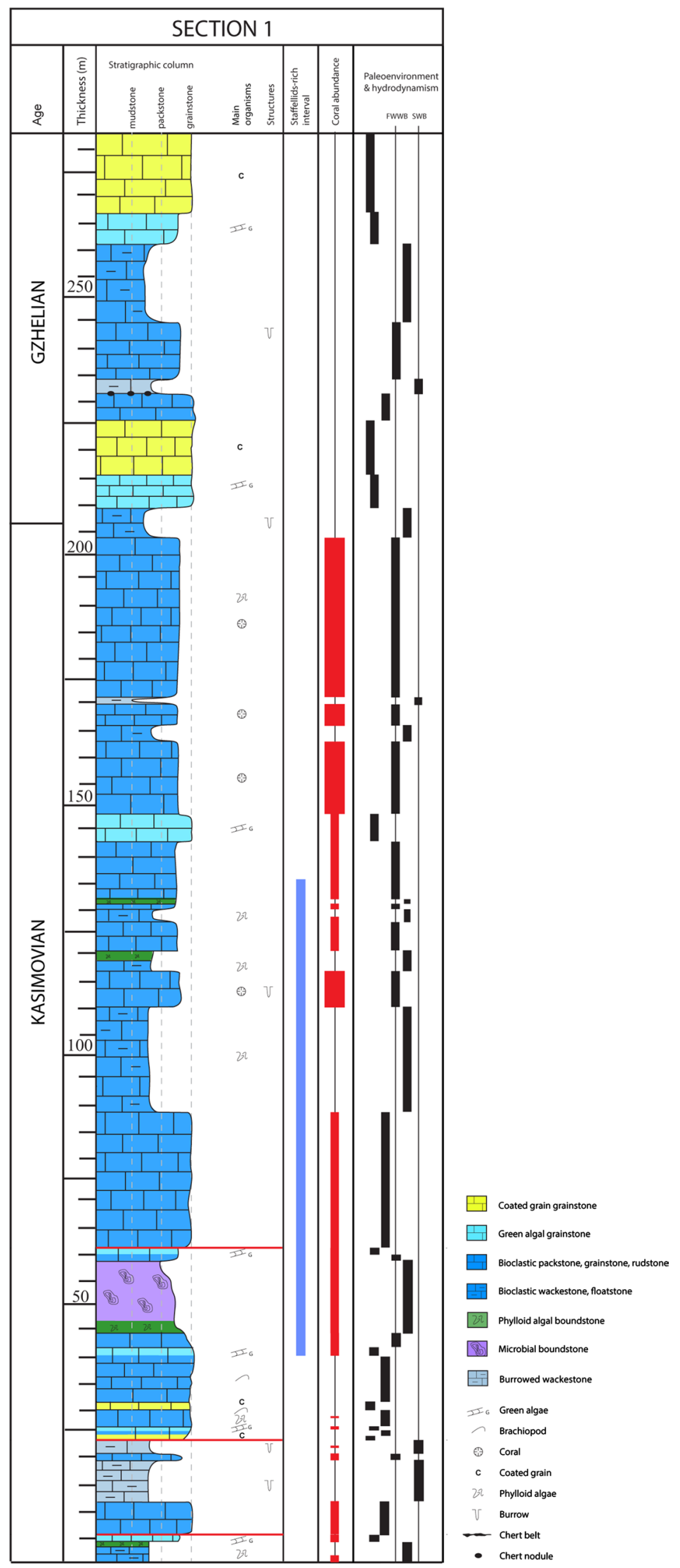




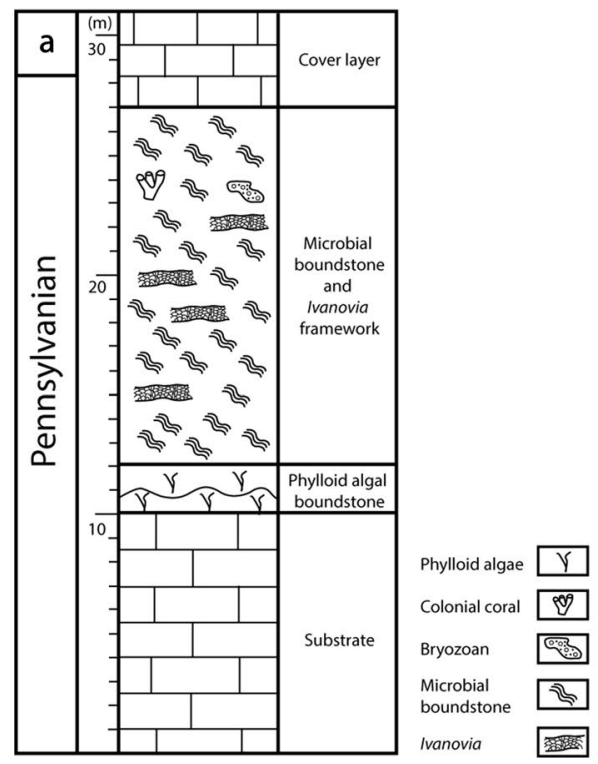

Fig. 14 Zhongxinzhai microbial mound. a Stratigraphic column of the Zhongxinzhai mound showing the composition and distribution of reef-building organisms. b Photograph of the mound core. The coral

influence the reef communities? Which global parameters could explain the limited coral reef development? And which specific setting could have led to the development of the Bianping coral reef, despite the generally unfavorable conditions globally?

\section{Paleoclimate: which impact on coral reef communities?}

\section{Bashkirian-Moscovian}

The Early Pennsylvanian (Bashkirian-Early Moscovian) coincides with a major glacial phase, with the expansion of ice-sheets in South America, southern Africa and Australia (Fielding et al. 2008a). Crowley et al. (1996) and Bruckschen et al. (1999) have estimated a tropical sea-surface temperature (SST) of about $20 \pm 5{ }^{\circ} \mathrm{C}, 5{ }^{\circ} \mathrm{C}$ lower than that prevailing during the Viséan.

The tropical sea-surface temperature is one of the primary controlling factors in the distribution of modern tropical coral reef ecosystems (Kleypas et al. 1999; Lough 2012). Currently, reef-building corals grow optimally between $23^{\circ}$ and $29^{\circ} \mathrm{C}$ (Spalding and Brown 2015), and spend $70 \%$ of the time within a $3{ }^{\circ} \mathrm{C} \mathrm{SST}$ range $\left(27-30{ }^{\circ} \mathrm{C}\right.$; Lough 2012$)$. Consequently, during the last decades, coral reefs occurred in the warmer part of the tropical oceans, living within $30^{\circ}$ latitude of the equator. Most warm-water corals exhibit a symbiotic relationship with zooxanthellae algae, from which they derive much of their nutrition. However, this relationship breaks down under seawater warming, inducing episode
Ivanovia (white arrow) grows on the microbial boundstone (black arrow). Modified from Huang et al. (2019)

of coral reef bleaching and mortality today (e.g. Baker et al. 2008; Hoegh-Guldberg 2011; Spalding and Brown 2015). Therefore, modern coral reefs, sensitive to seawater temperature, represent good indicators of climate changes.

Currently, even if a symbiosis between Paleozoic corals and algae is debated (Scrutton 1998; Copper and Scotese 2003), the Paleozoic coral reefs appear as adapted to soft substrates, warm waters and shelf seas (Scrutton 1998). The unequivocal evidence for this hypothesis is the radiation of the Paleozoic coral-stromatoporid reefs during the Devonian (Emsian-Givetian), the warmest period of the Phanerozoic (Copper and Scotese 2003). During this time-interval, the warm sea-surface temperature favored the formation of coral-stromatoporid mega-reefs and stretched them to high latitudes of at least $40^{\circ}-50^{\circ}$. Based on these findings, Paleozoic and modern coral reefs have in common an affinity for warm waters. Consequently, such as modern corals, it can be assumed that Paleozoic coral reefs were also affected by climate changes, especially cooling.

The investigation of the Carboniferous coral reef distribution tends to confirm this hypothesis. Indeed, during the Viséan (Mississippian) prior to the glaciation, numerous coralliferous reefs have been reported (e.g. Australia, Pickett 1967; Pickett and Wu 1990; Webb 1987, 1998; Shen and Webb 2005; UK and Ireland, Wolfenden 1958; Adams 1984; Aretz and Herbig 2003; Aretz et al. 2010; Canada, Schenk et al. 1984; Ukraine, Ogar 2012; China, Gong et al. 2012; Yao and Wang 2016; Maillet et al. 2020; Morocco, Rodriguez et al. 2012; Kazakhstan, Cook et al. 1994), distributed from Kazakhstan to Australia, in equatorial to the 

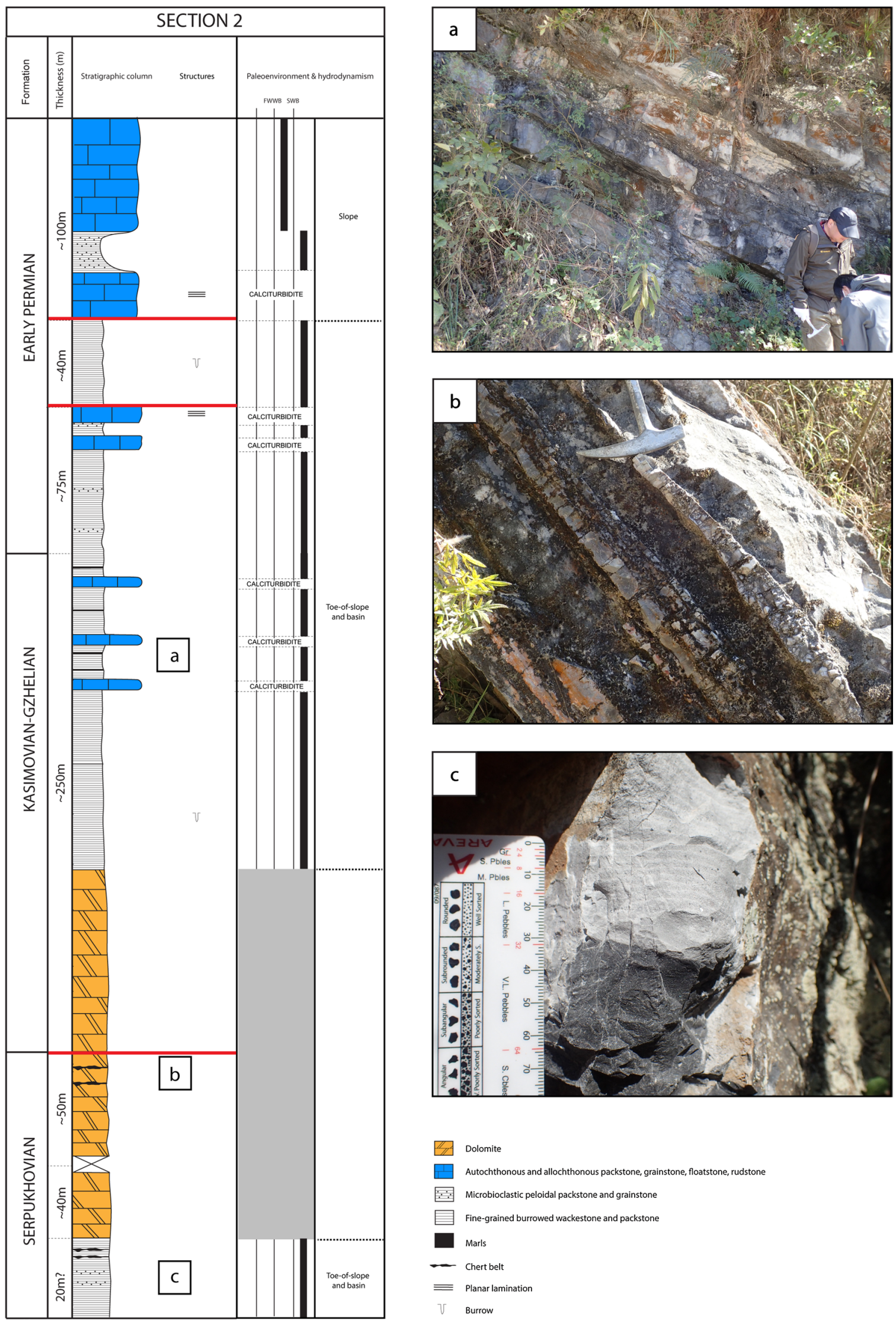
4Fig. 15 Lithofacies successions and paleoenvironments, from section 2 (Brickyard). During the latest Mississippian-earliest Pennsylvanian, lithofacies are commonly dolomitized, inhibiting the original texture to be identified. During this time-interval there is a probable unconformity, with the lack of Bashkirian deposits. During the Kasimovian-Early Permian (Asselian), lithofacies suggest toe-of-slope and basinal settings, accumulated in the Luodian intraplatform Basin. During the late Early Permian (Sakmarian), lithofacies indicate likely reef slope settings, which suggests a regression. a Field photograph of alternating of well-bedded fine-grained burrowed wackestone and packstone, thin marl and scarce allochthonous packstone and grainstone layers ( $<80 \mathrm{~cm}$ thick). b Field photograph of chert belts. c Field photograph of microbioclastic peloidal packstone and grainstone turbidite bed unit displaying small-scale ripple cross-lamination. The underlying layer is composed of fine-grained burrowed wackestone and packstone

subequatorial position (Fig. 18a). During the Serpukhovian and the initiation of the mid-Carboniferous glaciation, a clear decline of coralliferous reefs is observed (Fig. 18b) and the rare surviving coral reefs (e.g. Kazakhstan and USA) disappear during the Early Bashkirian, except in Japan. The mid-Carboniferous coral reef decline fairly correlated with the mid-Carboniferous climate transition, from the greenhouse to icehouse conditions. This correlation suggests that Paleozoic corals were most likely affected by cooling, and this environmental parameter played certainly a key role in the scarcity of Early Pennsylvanian coral reefs.

During the Bashkirian-Moscovian, new coral reefs developed in the Donets Basin (Ukraine), Cantabrian Mountains (Spain) and Moscow Basin (Russia) (Fig. 18c). All of these Early Pennsylvanian coralliferous reefs grew in lower latitudes, in the warmer part of the ocean, at the borders of the Paleo-Tethys Ocean and at the eastern border of the Panthalassa Ocean. The range of latitudes is significantly narrower than that of the Viséan, and climate cooling appears the most likely cause.

\section{Kasimovian-Gzhelian}

During the Late Pennsylvanian (Late Moscovian-Early Gzhelian), a relative climate warming occurred (Fielding et al. 2008a). While glacial retreat is observed in some regions (e.g. eastern Australia), other areas record continuing or intermittent glacial conditions (e.g. Oman, India, western Australia; Fielding et al. 2008a). However, despite the favorable climate warming, this period records a subordinate decline of coralliferous reefs, with only a few examples reported (e.g. Austria-Italy, southern China, Fig. 18d; Table 3). Therefore, paleoclimate can hardly explain the distribution of the Late Pennsylvanian coralliferous reefs, which leads to explore additional inhibiting factors for this period.

\section{Late Pennsylvanian: could biological competition explain the scarcity of coral reefs?}

The Late Pennsylvanian (Kasimovian-Gzhelian) is characterized by sea-level fluctuations of high amplitude, varying from 10 to $120 \mathrm{~m}$ (Ross and Ross 1987, 1988; Maynard and Leeder 1991; Haq and Schutter 2008; Rygel et al. 2008; Davydov et al. 2012), with a periodicity within the Milankovitch ranges (Harrison et al. 1979; Ross and Ross 1987; Heckel et al. 2007). These environmental conditions promoted the proliferation of phylloid algae, becoming the most abundant shallow-waters reef builders until the Permian. This radiation is attributed to the rapid reproduction and growth rates of phylloid algae, which enabled them to colonize shallow-water areas rapidly and outcompete other organisms for optimum living space. This opportunistic growth strategy was ideally suited to the cyclic glacioeustasy of the Pennsylvanian-Early Permian, which caused shallow-shelf areas to be repeatedly exposed and drowned at relatively frequent intervals (Wahlman 2002). Therefore, shallow-water shelf and shelf-margin ecological niches were newly occupied by phylloid algae (Wilson 1975), to the detriment of less adaptative and less opportunistic corals, making their recovery difficult to succeed.

In southern China, corals and phylloid algae do not occur in the same horizons (Fig. 13). Within the Bianping coral reef, phylloid algae contributed to the initiation of the reefbuilding under shallow and agitated waters (above or around the FWWB). However, with the increase of water depth, phylloid algae disappeared and gave way to brachiopods and branching colonial corals. Thus, the present study demonstrates that coral communities were able to colonize a deeper water setting, where they were not in competition with the contemporaneous opportunistic phylloid algal community that dominated shallower water environments. This coral growth strategy could explain the discovery of the Bianping coral reef in southern China and possibly the auloporid coral mounds reported in the Carnic Alps (Austria-Italy), growing in low-energy environments. However, the scarcity of coral reefs worldwide, even in deeper environments, leads to explore additional inhibiting factors.

\section{Seawater chemistry}

\section{Pennsylvanian aragonite seas}

Throughout the Phanerozoic, seawater had oscillated between aragonite and calcite seas, favoring the precipitation of either high-Mg calcite and aragonite or low-Mg calcite (Sandberg 1983; Fig. 19). The intervals of calcite and aragonite production are thought to be caused primarily by secular variations in the $\mathrm{Mg} / \mathrm{Ca}$ ration of seawater (e.g. Stanley and Hardie 1998). These oscillations tend to 


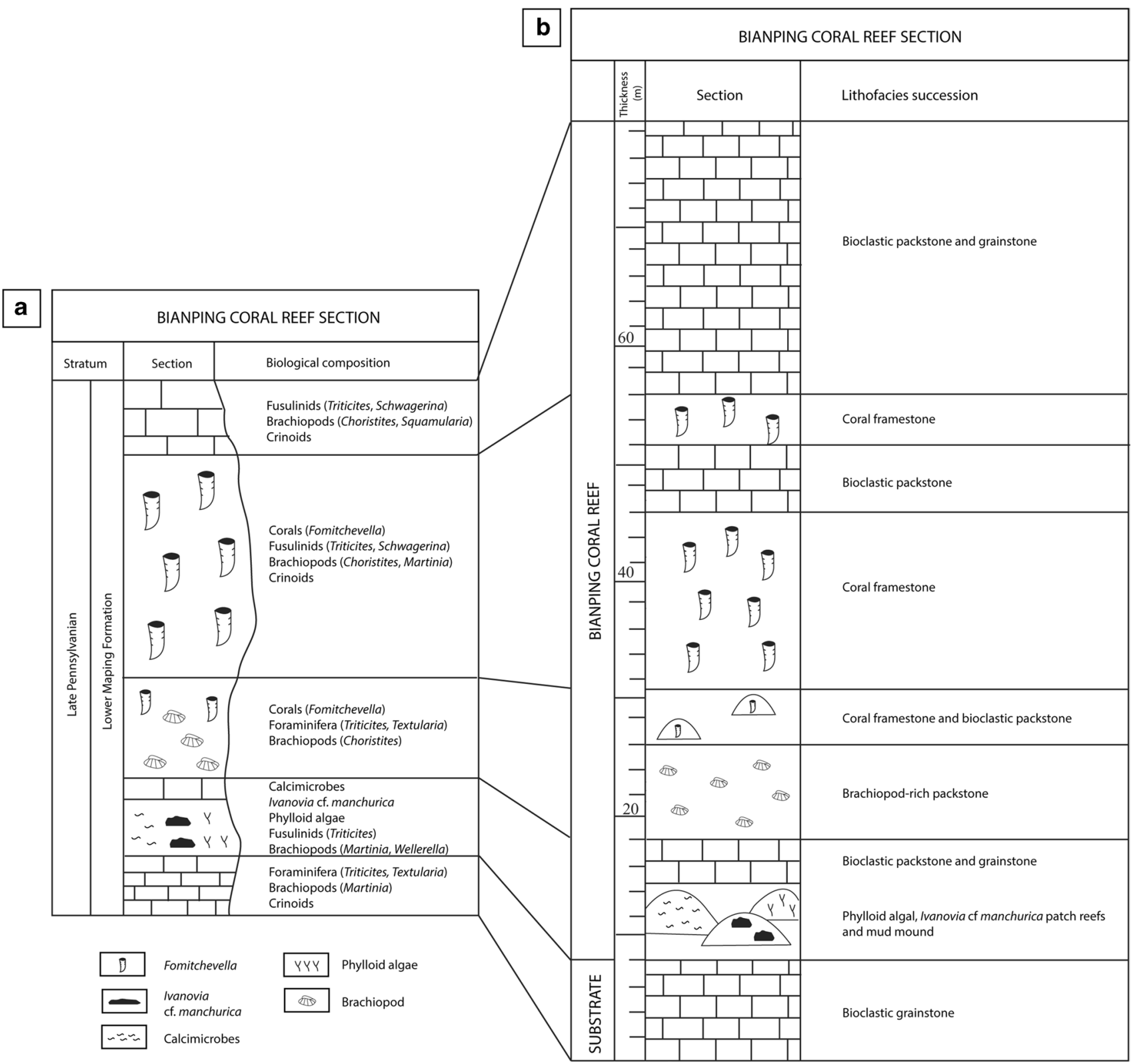

Fig. 16 Bianping coral reef sections. a A summary of the biological composition of the Bianping coral reef, modified from Gong et al. (2012). b Bianping coral reef section showing the lithofacies succession, modified from Gong et al. (2004)

correspond to changes in the mineralogy of abiotic as well as biotic carbonates (Stanley and Hardie 1998, 1999; Ries et al. 2006; Kiessling et al. 2008). For example, in the Early and Mid-Paleozoic calcite seas (Ordovician-Mississippian), reefs were dominated by calcitic tabulate, heliolitid, rugose corals and calcitic stromatoporoid sponges (Wood 1987). Conversely, in the Late Paleozoic-Early Mesozoic aragonite seas, reef-builders were dominated by phylloid algae (Pennsylvanian-Permian), scleractinian corals (Early Mesozoic) and high-Mg calcite ancestral coralline algae (Stanley and Hardie 1998). Therefore, the fluctuations of seawater composition impacted biocommunities, constraining them to evolve (e.g. Hautmann 2006) or disappear.

In the aragonite seas of the Pennsylvanian, shallowwater buildups are dominated by aragonitic components (e.g. phylloid algae, chaetetid sponges, aragonite cement) and high-Mg calcite skeletons (e.g. Archaeolithophyllum red algae, Tubiphytes) and cements (e.g. radiaxial; Wendt 1977; Wray 1977; Stanley and Hardie 1998). Low-Mg calcite 


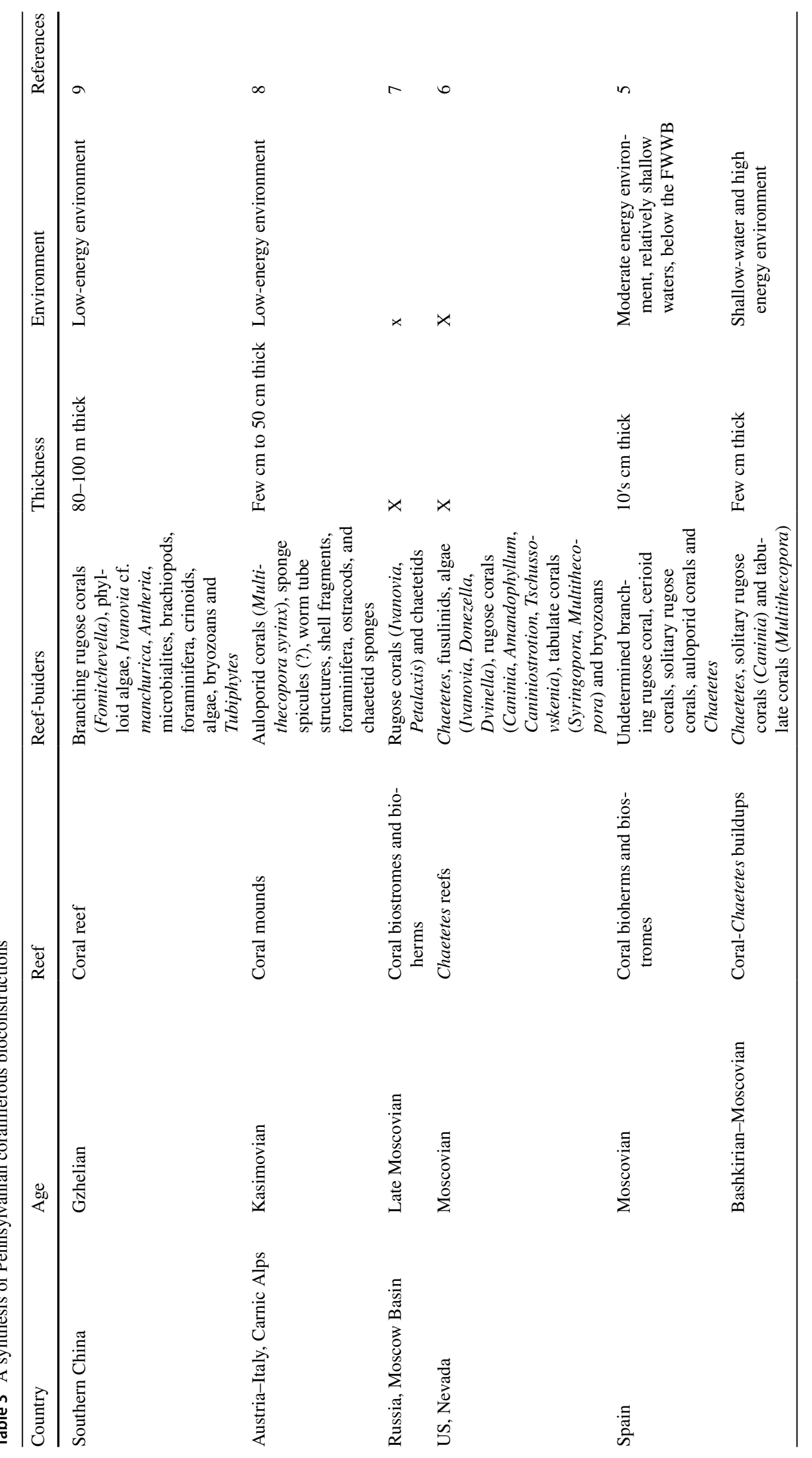




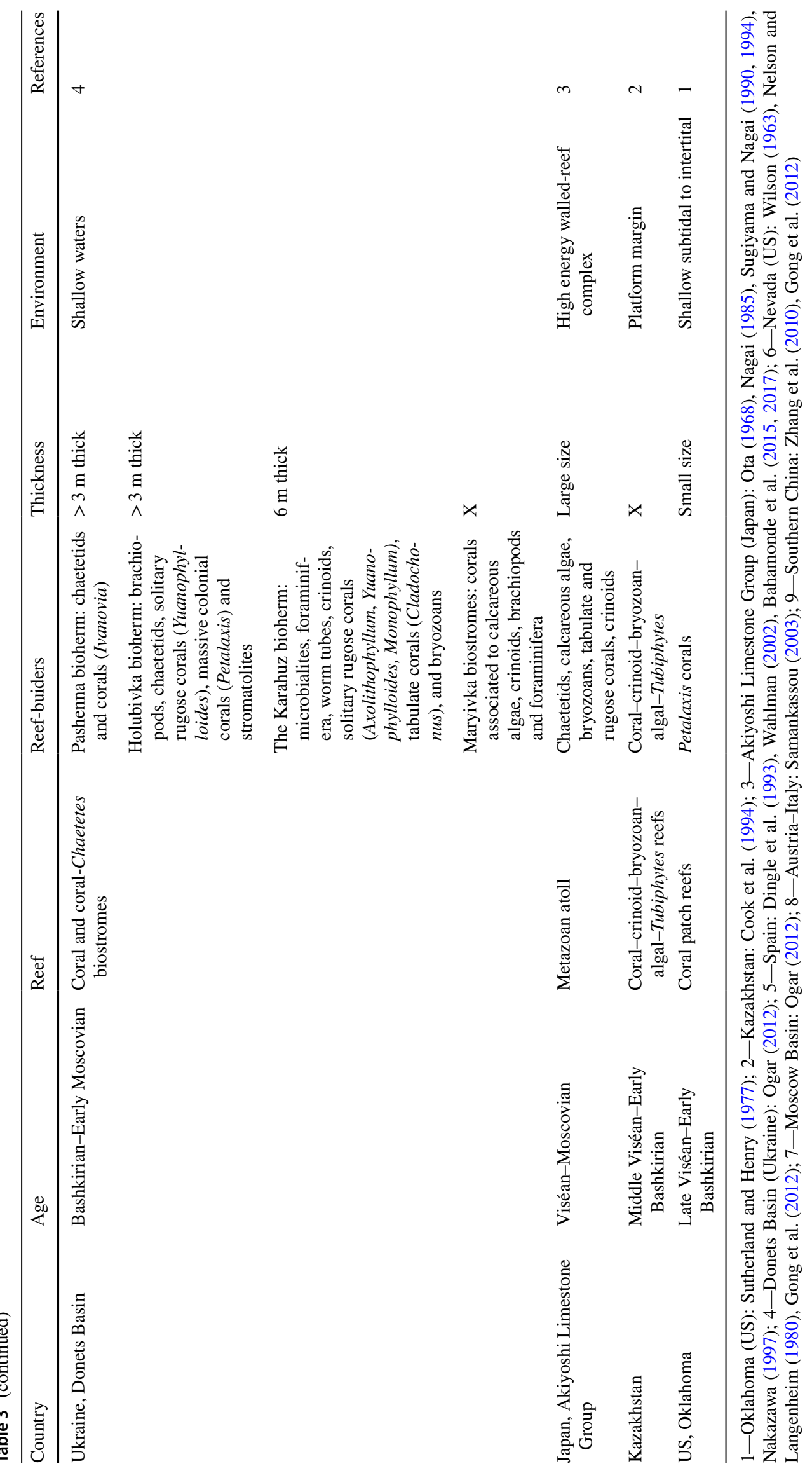




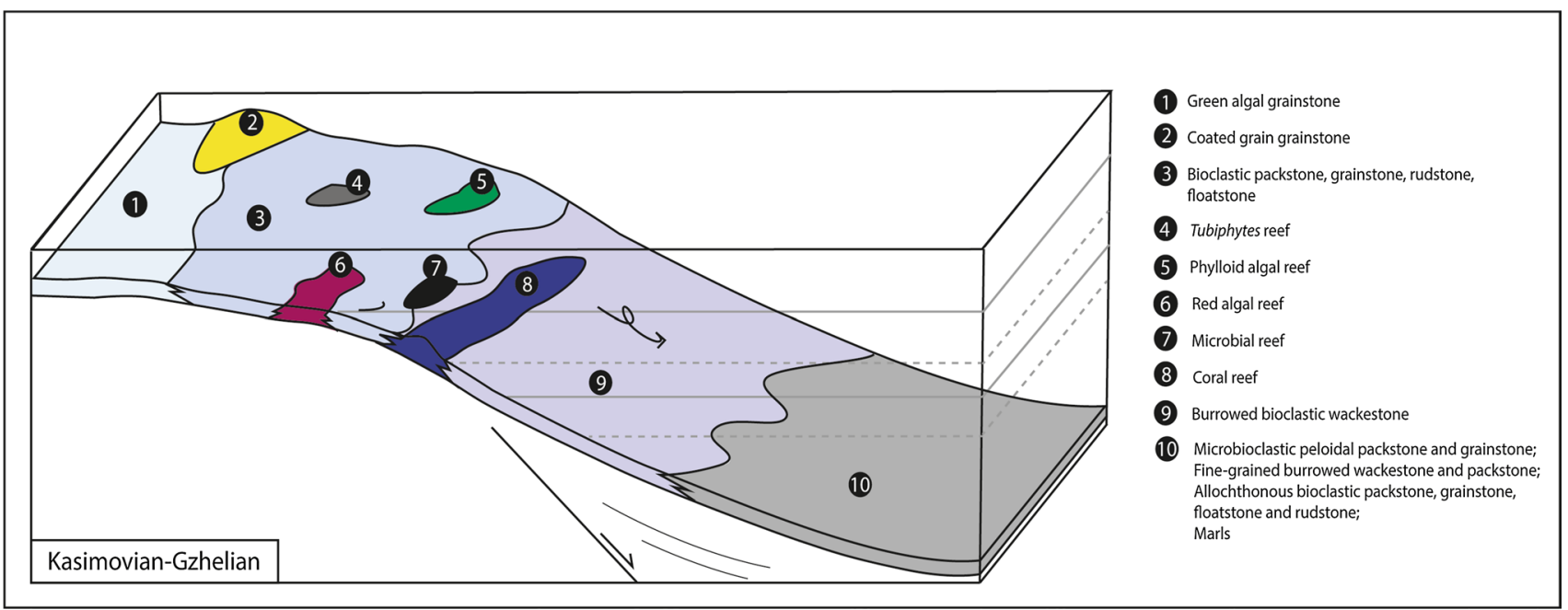

Fig. 17 Kasimovian-Gzhelian platform model, records from Houchang (southern China). Coated-grain grainstone and green algal grainstone lithofacies types deposited in shallow waters and shoals. In situ bioclastic pack-, grain-, rud- and float-stone lithofacies type deposited around the FWWB, within the photic zone, whereas allochthonous bioclastic pack-, grain-, rud- and float-stone were reworked and deposited from peri-reefal to basinal settings. The burrowed bioclastic wackestone, microbioclastic peloidal packstone and grainstone, fine-grained burrowed wackestone and packstone and marls

components (e.g. bryozoan), also present, are subordinate (Wahlman 2002).

In Houchang (southern China), Late Pennsylvanian (Kasimovian-Gzhelian) bioconstructions were built by chaetetid sponges, phylloid algae, Tubiphytes and corals (Table 1). Globally, the poor microstructural preservation of chaetetid sponges and phylloid algae points to an original aragonitic composition (Stanley and Hardie 1998; Flügel 2010). Tubiphytes secreted high-Mg calcite (Senowbari-Daryan and Flügel 1991). Conversely, the mineralogy of Paleozoic corals is more debated. Sorauf (1996) argues in favor of lowMg calcite skeletons whereas Scrutton (1997) suggests that rugose and tabulate corals secreted intermediate-Mg calcite $(<8 \mathrm{~mol} \% \mathrm{MgCO} 3)$, and Heterocorallia precipitated low- $\mathrm{Mg}$ calcite skeletons. Other authors postulated an evolution of coral mineralogy through the Paleozoic: Devonian rugose corals had low-Mg calcite skeletons (Tabulophyllum: 0.5 weight\% MgO, Sorauf 1997) whereas Pennsylvanian corals (Lophophyllum) precipitated original intermediate-Mg calcite skeletons (5-8 mol\% $\mathrm{MgCO}_{3}$, Brand 1981; Webb and Sorauf 2002). The evolution of the Paleozoic coral mineralogy is attributed to the seawater chemistry and the transition from calcite to aragonite seas. Based on this assumption, all coral genera were certainly not able to evolve and most disappeared during the transition in seawater chemistry which deposited in low energy environment, below the SWB, into the slope and basinal environment. In Houchang, phylloid algal reefs, microbial mounds, sponge mounds and Tubiphytes reefs grew in shallow-waters (Yao and Wang 2016). Conversely, the large Bianping coral reef was initiated in shallow-waters, mainly built by Ivanovia, calcimicrobes and phylloid algae, but grew with the increase of water-depth allowing the development of Fomitchevella branching corals, below the FWWB

could partly explain the decline of the coralliferous bioconstructions during the mid-Carboniferous.

This theory would suggest that all Pennsylvanian coral reef genera, including the rugose corals Yuanophylloides, Axolithophyllum, Monophyllum, Caninia, Amandophyllum, Caniniostrotion, Tschussovskenia, Petalaxis, Fomitchevella and Cladochonus, Syringopora, and tabulate coral Multithecopora (Table 3), precipitated intermediate- $\mathrm{Mg}$ calcite skeletons. However, this hypothesis is currently not demonstrated and it cannot be excluded that some of these corals precipitated low-Mg calcite skeletons.

\section{How could the coexistence of aragonite and high-Mg calcite components with low-Mg calcite corals be explained?}

From the Early to Late Pennsylvanian, a brief drop in $\mathrm{Mg} / \mathrm{Ca}$ ratio of seawater is recorded, from about 4.2-2 mol (Stanley and Hardie 1998; Fig. 19). In theory, this decline could promote the coexistence of aragonite, high-Mg calcite and low-Mg calcite skeletons during the Kasimovian-Gzhelian. However, several bioconstructions, including calcite corals, have been also reported from the Early Pennsylvanian (Bashkirian-Moscovian, Table 3), when the $\mathrm{Mg} / \mathrm{Ca}$ ratio of seawater was high (about $4.2 \mathrm{~mol}$ ), which seems to invalidate this first hypothesis. 
Fig. 18 Geographical distribution of Pennsylvanian coralliferous bioconstructions plotted in Late Viséan (a) and Moscovian (b-d) paleogeographic maps (modified from Webb 2002). a Geographical distribution of Viséan coralliferous buildups. 1-Nova Scotia (Canada): Schenk et al. (1984); 2-England, southern Wales, Ireland: Wolfenden (1958), Aretz and Herbig (2003), Shen and Webb (2005), Aretz et al. (2010); 3-Morocco: Rodríguez et al. (2012); 4-Ukraine: Ogar (2012); 5-Kazakhstan: Cook et al. (1994); 6-Southern China: Gong et al. (2012), Maillet et al. (2020); 7-Japan: Ota (1968), Nagai (1985), Sugiyama and Nagai $(1990,1994)$, Nakazawa (1997); 8-Queensland (Australia): Webb (1987, 1998), Shen and Webb (2005); 9-New South Wales (Australia): Pickett (1967), Pickett and Wu (1990). b Geographical distribution of SerpukhovianEarly Bashkirian coralliferous biosonstructions. 1-Oklahoma (US): Sutherland and Henry (1977); 2-Urals (Kazakhstan): Cook et al. (1994); 3-Honshu (Japan): Ota (1968), Nagai (1985), Sugiyama and Nagai (1990,1994), Nakazawa (1997). c Geographical distribution of Bashkirian-Moscovian coralliferous biosonstructions. 1Nevada (US): Wilson (1963); Nelson and Langenheim (1980); Gong et al. (2012); 2-Moscow Basin: Ogar (2012); 3-Donets Basin (Ukraine): Ogar (2012); 4-Cantabrian mountains (Spain): Dingle et al. (1993), Wahlman (2002), Bahamonde et al. (2015, 2017); 5-Honshu (Japan): Ota (1968), Nagai (1985), Sugiyama and Nagai (1990,1994); Nakazawa (1997). d Geographical distribution of Kasimovian-Gzhelian coralliferous biosonstructions. 1-Austria-Italy: Samankassou (2003); 2-Southern China: Zhang et al. (2010); Gong et al. (2012)
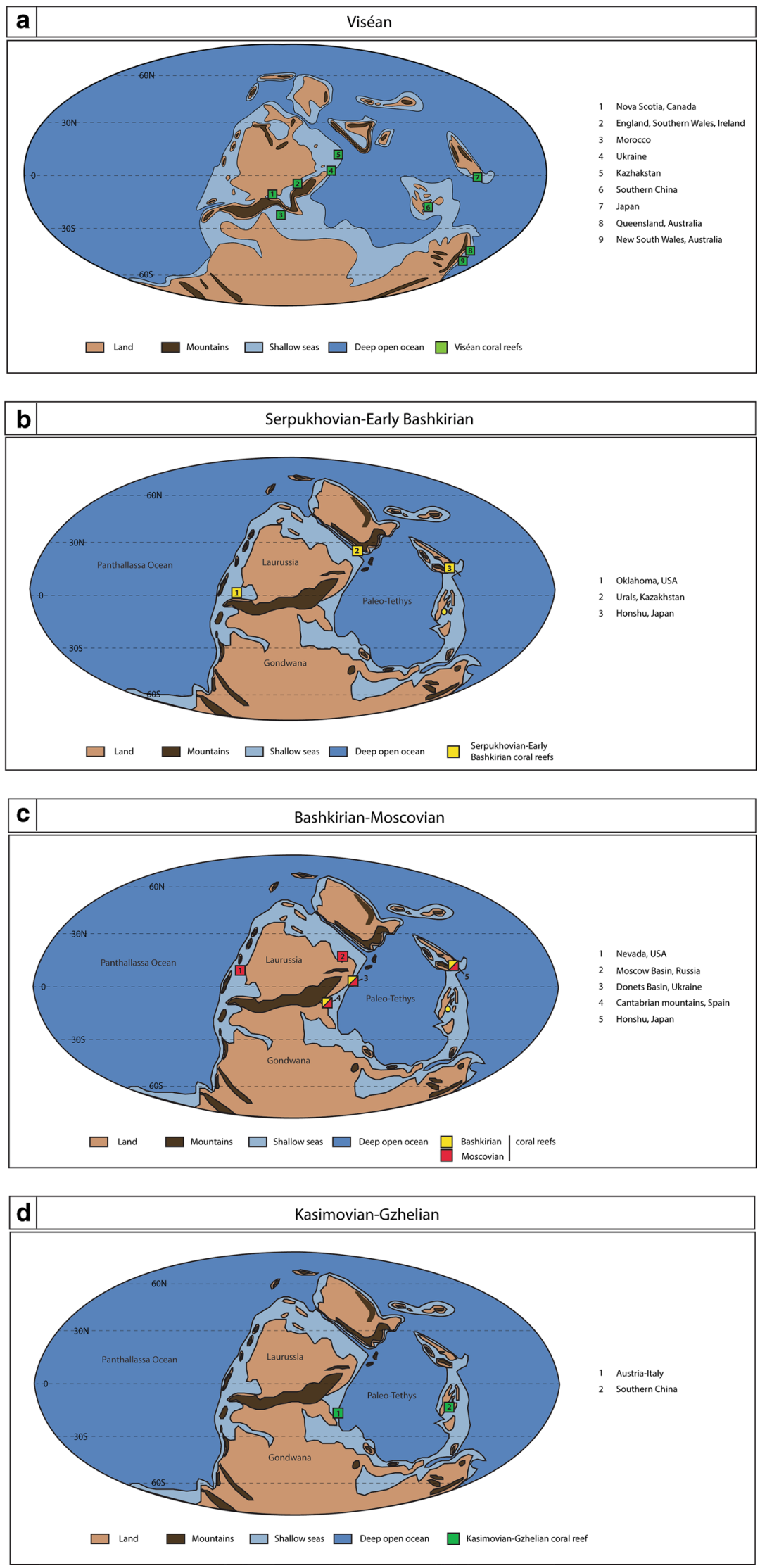


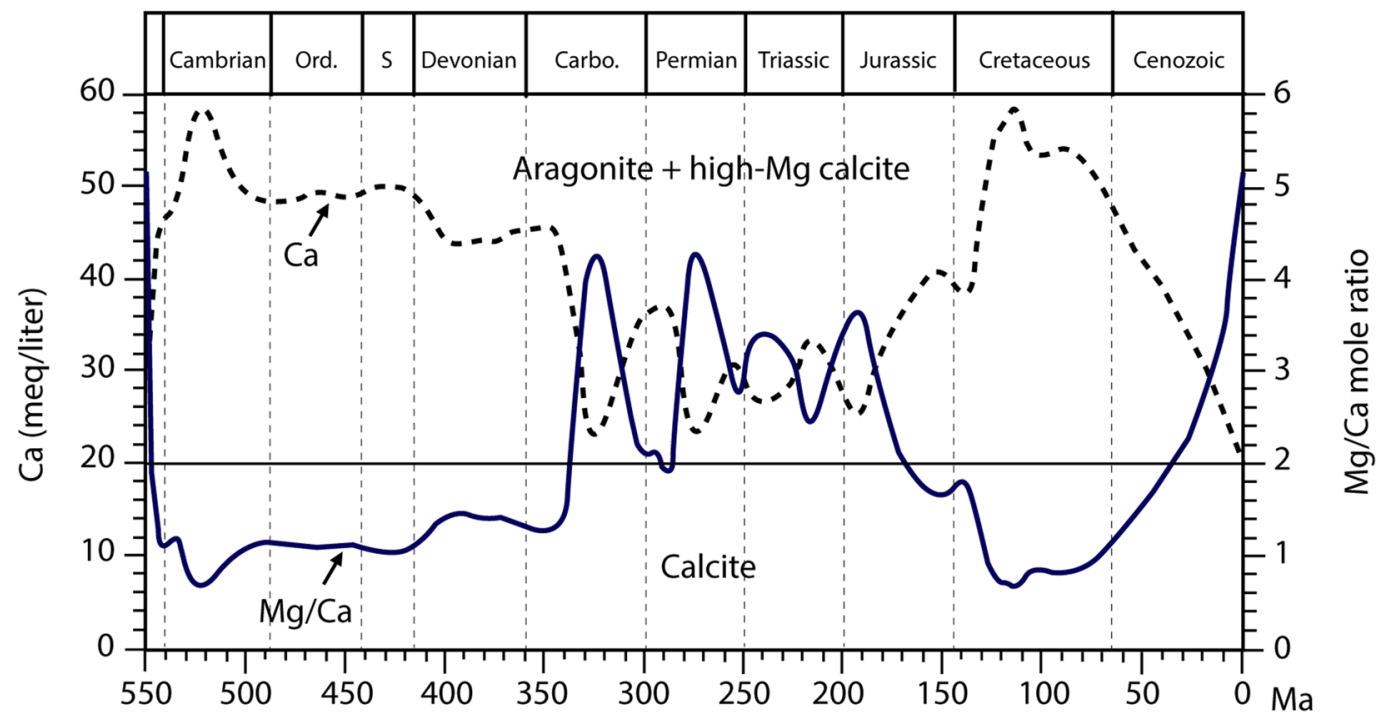

Sandberg

$(1983,1985)$

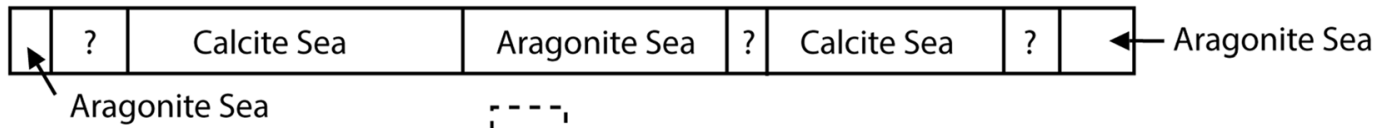

Aragonite Sea

Main Pennsylvanian

reef builders

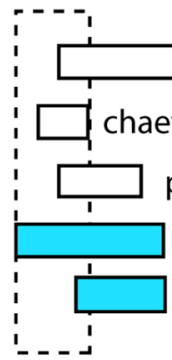

dasycladaceans

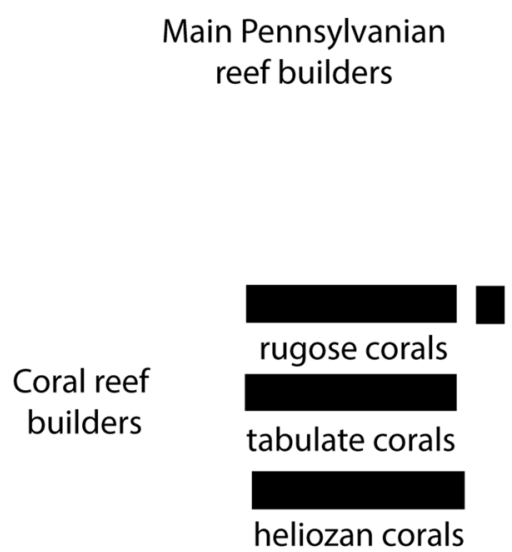

phylloid algae

ancestral coralline

Tubiphytes

$-1$

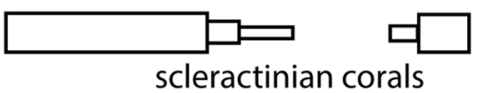

Skeletal mineralogy:

calcite

aragonite

Mg-calcite

Fig. 19 Phanerozoic secular oscillations in seawater chemistry (Stanley and Hardie 1998), between aragonite and calcite seas, favoring the precipitation of either high-Mg calcite and aragonite or low-Mg calcite. The boundary between the nucleation fields of low-Mg calcite and aragonite/high- $\mathrm{Mg}$ calcite is at $\mathrm{Mg} / \mathrm{Ca}=2$. During the Pennsylva-

Other studies (e.g. Adabi 2004) reveal that, even if biotic and abiotic carbonates follow the general trend of calcite seas and aragonite seas (Sandberg 1983), a coexistence of organisms with calcite and aragonite mineralogy is possible, depending on environmental conditions. In the "aragonite seas", the precipitation of high-Mg calcite and aragonite would be favored in low latitudes and shallow-waters. nian aragonite seas, reef builders are dominated by chaetetids, phylloid algae, ancestral coralline and Tubiphytes, precipitating aragonite and high-Mg calcite skeletons. System boundaries have been updated using McArthur et al. (2012). Carbo carboniferous, Ord ordovician, $S$ silurian

Conversely, the precipitation of low-Mg calcite biota and cements would be possible thanks to cooling, decreasing of light, high paleolatitudes or increasing paleobathymetry (Wahlman 2002; Adabi 2004). This assumption is currently used to explain the occurrence of the large Viséan-Moscovian reef complex in the tropical seas of Japan. The abundance of corals in the Akiyoshi reef complex is currently 
attributed to the location: it formed atoll-like reef on a seamount, where they would have been exposed to the upwelling of cold open-ocean seawater (Wahlman 2002).

However, worldwide, Early Pennsylvanian coralliferous bioconstructions were mainly present in low latitudes (Fig. 18c) and shallow-waters (Table 3). Therefore, the precipitation of low-Mg calcite corals cannot be attributed to the decreasing of light, high paleolatitudes or increasing paleobathymetry. The remaining hypothesis would be climate cooling. However, this statement appears incompatible with the development of tropical corals, which raises new questions about the factors controlling this coexistence.

\section{How can the existence of the Late Pennsylvanian Bianping coral reefs be explained?}

During the Late Pennsylvanian, the main factor inhibiting the development of coral buildups was probably biological competition with calcareous algal communities, and seawater chemistry might also have played a role. During this period, only two coral reefs have been reported in Austria-Italy and southern China. It is interesting to note that both reefs occur in a low-energy depositional environment, below the FWWB. This depositional environment differs from that of the Early Pennsylvanian, where coral reefs grew commonly in shallow waters, above the FWWB. Therefore, the deeper depositional environment where the competition of corals with phylloid algae is reduced most likely favored the development of coral communities building the large reef of the present study.

\section{Conclusions}

1. In Houchang (southern China), the Kasimovian-Gzhelian carbonate platform records a high diversity of bioconstructions, including Tubiphytes reefs, sponge reefs, phylloid algal reefs, microbial mounds and a large coral reef, growing at the margin of a shelfal depression.

2. The existence of the large Bianping coral reef is uncommon for the Pennsylvanian, lacking any analogs in age (Gzhelian), size (80-100 m thick) and composition (Fomitchevella, phylloid algae, the corals Ivanovia and Antheria, microbialites, brachiopods, fusulines, crinoids, algae, bryozoans, Tubiphytes).

3. The large coral reef (southern China) was initiated in shallow waters, with the deposition of phylloid algal, the coral Ivanovia and microbial patch reefs. But the reef core composed of branching corals formed when water-depth increased, with the reef growth occurring below the FWWB.

4. The carbonate platform records the deposition of green algal grainstone, coated grain grainstone and bioclas- tic packstone, grainstone, floatstone and rudstone in shallow-waters, and burrowed bioclastic wackestone, microbioclastic peloidal packstone and grainstone, and fine-grained burrowed wackestone and packstone in the deep-water shelfal depression. In this context, the coral reef developed in the deep shelf margin, in a moderate to low energy depositional environment.

5. The investigation of the Pennsylvanian environmental conditions reveals global inhibiting factors leading to the scarcity of Pennsylvanian coral reefs:

- The Early Pennsylvanian cooling fairly correlates with a decline of coralliferous bioconstructions. However, during the Late Pennsylvanian, despite the short-lived climate warming, this period records a subordinate decline of coral buildups. Therefore, paleoclimate could explain the collapse of the Early Pennsylvanian coral reefs but cannot explain the distribution of the Late Pennsylvanian reefs.

- The Late Pennsylvanian coincides with the radiation of phylloid algae, more opportunistic and adaptative than corals, that occupied most of the shallow and warm waters. Consequently, the biological competition could explain the scarcity of coral reefs during the Late Pennsylvanian.

- The Carboniferous is characterized by the transition from calcite (Mississippian) to aragonite seas (Pennsylvanian). Paleozoic corals, precipitating low to intermediate $\mathrm{Mg}$ calcite skeletons, were likely affected by the seawater chemistry evolution, which could explain the coral reef collapse. However, additional investigations on coral skeletons are needed to confirm this hypothesis.

6. During the Late Pennsylvanian, the main factor inhibiting the development of coral buildups was probably biological competition with calcareous algal communities, and seawater chemistry might also have played a role. However, the deeper depositional environment where the competition of corals with phylloid algae is reduced most likely favored the development of coral communities building the large reef of the present study.

Acknowledgements We thank the reviewers (Dr G. Della Porta and Dr G. P. Wahlman) for having provided very constructive and insightful comments and Dr W. Kiessling for his editorial advice. This study was supported by the Swiss National Science Foundation [Grant number 200021_160019] and the National Natural Science Foundation of China [Grant numbers 41572004 and 41972002].

Funding Open access funding provided by University of Geneva.

Open Access This article is licensed under a Creative Commons Attribution 4.0 International License, which permits use, sharing, adaptation, distribution and reproduction in any medium or format, as long as you give appropriate credit to the original author(s) and the source, provide a link to the Creative Commons licence, and indicate if changes 
were made. The images or other third party material in this article are included in the article's Creative Commons licence, unless indicated otherwise in a credit line to the material. If material is not included in the article's Creative Commons licence and your intended use is not permitted by statutory regulation or exceeds the permitted use, you will need to obtain permission directly from the copyright holder. To view a copy of this licence, visit http://creativecommons.org/licenses/by/4.0/.

\section{References}

Adabi MH (2004) A re-evaluation of aragonite versus calcite seas. Carbonates Evaporites 19:133-141

Adams AE (1984) Development of algal-foraminiferal-coral reefs in the Lower Carboniferous of Furness, northwest England. Lethaia 17:233-249

Aretz M, Herbig HG (2003) Coral-rich bioconstructions in the Viséan (Late Mississippian) of southern Wales (Gower Peninsula, UK). Facies 49:221-242

Aretz M, Herbig HG (2008) Microbial-sponge and microbial-metazoan buildups in the Late Viséan basin-fill sequence of the Jerada Massif (Carboniferous, NE Morocco). Geol J 43:307-336

Aretz M, Herbig HG, Somerville ID, Cózar P (2010) Rugose coral biostromes in the late Viséan (Mississippian) of NW Ireland: bioevents on an extensive carbonate platform. Palaeogeogr Palaeoclimatol Palaeoecol 292:488-506

Bahamonde JR, Merino-Tomé OA, Heredia N (2007) A Pennsylvanian microbial boundstone-dominated carbonate shelf in a distal foreland margin (Picos de Europa Province, NW Spain). Sed Geol 198:167-193

Bahamonde JR, Merino-Tomé O, Della Porta G, Villa E (2015) Pennsylvanian carbonate platforms adjacent to deltaic systems in an active marine foreland basin (Escalada Fm., Cantabrian Zone, NW Spain). Basin Res 27:208-229

Bahamonde JR, Della Porta G, Merino-Tomé OA (2017) Lateral variability of shallow-water facies and high-frequency cycles in foreland basin carbonate platforms (Pennsylvanian, NW Spain). Facies 63:6

Baker AC, Glynn PW, Riegl B (2008) Climate change and coral reef bleaching: an ecological assessment of long-term impacts, recovery trends and future outlook. Estuar Coast Shelf Sci 80:435-471

Barash MS (2017) Environmental conditions as the cause of the great mass extinction of marine organisms in the Late Devonian. Dokl Earth Sci 475:845-848

Beauchamp B, Davies GR, Nassichuk WW (1989) Upper Carboniferous to Lower Permian Palaeoaplysina-phylloid algal buildups, Canadian Arctic Archipelago. In: Geldsetzer HHJ, James NP, Tebbutt GE (eds) Reefs, Canada and adjacent areas. Canadian Society of Petroleum Geologists, Memoir 13, pp 590-599

Brand U (1981) Mineralogy and chemistry of the Lower Pennsylvanian Kendrick fauna, eastern Kentucky. Chem Geol 32:1-16

Brand U (1989) Global climatic changes during the Devonian-Mississippian: stable isotope biogeochemistry of brachiopods. Palaeogeogr Palaeoclimatol Palaeoecol 75:311-329

Bruckschen P, Oesmann S, Veizer J (1999) Isotope stratigraphy of the European Carboniferous: proxy signals for ocean chemistry, climate and tectonics. Chem Geol 161:127-163

Buggisch W (1991) The global Frasnian-Famennian "Kellwasser Event.” Geol Rundsch 80:49-72

Caputo MV, Melo JHG, Streel M, Isbell JL (2008) Late Devonian and Early Carboniferous glacial records of South America. In: Fielding CR, Frank TD, Isbell JL (eds) Resolving the Late Paleozoic Ice Age in time and space. Geological Society of America, Special Paper 441, pp 161-173
Casier JG, Mamet B, Préat A, Sandberg CA (2004) Sedimentology, conodonts and ostracods of the Devonian-Carboniferous strate of the Anseremme railway bridge section, Dinant Basin, Belgium. Bulletin de l'Institut Royal des Sciences Naturelles de Belgique Sciences de la Terre 74:45-68

Chang HL, Dong XM, Gong EP, Guan CQ, Zhang YL, Sun BL, Yang LL, Li JM (2008) Research on coral reef ecosystem of the late Carboniferous in the southern of Guizhou. Acta Sedimentol Sin 26:904-912

Chappell J (1980) Coral morphology, diversity and reef growth. Nature 286:249-252

Chen J, Chough SK, Han Z, Lee JH (2011) An extensive erosion surface of a strongly deformed limestone bed in the Gushan and Chaomidian formations (late Middle Cambrian to Furongian), Shandong Province, China: sequence-stratigraphic implications. Sed Geol 233:129-149

Connolly WM, Lambert LL, Stanton RJ (1989) Paleoecology of Lower and Middle Pennsylvanian (Middle Carboniferous) Chaetetes in North America. Facies 20:139-168

Cook HE, Zhemchuzhnikov VG, Buvtshkin VM, Golub LY, Gatovsky YA, Zorin AY (1994) Devonian and Carboniferous passive-margin carbonate platform of southern Kazakhstan: summary of depositional and stratigraphic models to assist in the exploration and production of coeval giant carbonate platform oil and gas fields in the North Caspian Basin, western Kazakhstan. In: Embry AF, Beauchamp B, Glass DJ (eds) Pangea: Global environments and ressources. Canadian Society of Petroleum Geologists, Memoir 17, pp 1-47

Copper P (1986) Frasnian/Famennian mass extinction and cold-water oceans. Geology 14:835-840

Copper P (2002) Reef development at the Frasnian/Famennian mass extinction boundary. Palaeogeogr Palaeoclimatol Palaeoecol $181: 27-65$

Copper P, Scotese CR (2003) Megareefs in Middle Devonian supergreehouse climates. In: Chan MA, Archer AW (eds) Extreme depositional environments: mega end members in geologic time: Boulder, Colorado. Geological Society, Special Paper 370, pp 209-230

Crowley TJ, Yip KJJ, Baum SK, Moore SB (1996) Modeling Carboniferous coal formation. Paleoclimates 2:159-177

Davydov VI, Crowley JL, Schmitz MD, Poletaev VI (2010) Highprecision $\mathrm{U}-\mathrm{Pb}$ zircon age calibration of the global Carboniferous time scale and Milankovitch band cyclicity in the Donets Basin, eastern Ukraine. Geochem Geophys Geosyst. https://doi. org/10.1029/2009GC002736

Davydov V, Korn D, Schmitz MD (2012) The Carboniferous period. In: Gradstein FM, Ogg JG, Schmitz MD, Ogg GM (eds) The geologic time scale 2012. Elsevier, Amsterdam, pp 603-651

Dawson O, Racey A (1993) Fusuline-calcareous algal biofacies of the Permian Ratburi Limestone, Saraburi, Central Thailand. J SE Asian Earth Sci 8:49-65

Della Porta G, Kenter JAM, Immenhauser A, Bahamonde JR (2002) Lithofacies character and architecture across a Pennsylvanian inner-platform transect (Sierra del Cuera, Asturias, Spain). Sediment Res 72:898-916

Della Porta G, Kenter JAM, Bahamonde JR, Immenhauser A, Villa E (2003) Microbial boundstone dominated carbonate slope (Upper Carboniferous, N Spain): microfacies, lithofacies distribution and stratal geometry. Facies 49:175-207

Dingle PS, Bader B, Hensen C, Minten B, Schafer P (1993) Sedimentology and paleoecology of Upper Carboniferous shallow-water carbonate complexes of the Carmenes Syncline (Cantabrian Mts., N-Spain). Zeitschrift der Deutschen Geologischen Gesellschaft 144:370-395

Dunham RJ (1962) Classification of carbonate rocks according to depositional textures. In: Ham WE (ed) Classification of carbonate 
rocks-a symposium. Tulsa, American Association of Petroleum Geologists 1, pp 108-121

Embry AF, Klovan JE (1971) A Late Devonian reef tract on Northeastern Banks Island, NWT. Can Petrol Geol Bull 19:730-781

Erfani S, Adabi MH, Majidifard MR, Ghadimvand NK (2016) Facies interpretation, depositional environment and sequence stratigraphy of the Gachal Formation in the Madbeiki section, Kalmard Block, East Central Iran. Open J Geol 6:439-458

Fagerstrom JA (1987) The evolution of reef communities. Wiley, New York

Fan SX, Rigby JK (1994) Upper Carboniferous phylloid algal mounds in South Guizhou, China. In: Kowallis BJ, Seely K (eds) Brigham Young University Geology Studies. Brigham Young University Press 40, Provo, pp 17-24

Feng ZZ, Yang YQ, Bao ZD (1998) Lithofacies paleogeography of the Carboniferous in South China. Palaeogeography 1:75-86 (in Chinese, with English abstract)

Fielding CR, Frank TD, Isbell JL (2008a) The Late Paleozoic Ice Age - a review of current understanding and synthesis of global climate patterns. In: Fielding CR, Frank TD, Isbell JL (eds) Resolving the Late Paleozoic Ice Age in time and space. Geological Society of America, Special Paper 441, pp 343-354

Fielding CR, Frank TD, Birgenheier LP, Rygel MC, Jones AT, Roberts J (2008b) Stratigraphic record and facies associations of the Late Paleozoic ice age in eastern Australia (New South Wales and Queensland). In: Fielding CR, Frank TD, Isbell JL (eds) Resolving the Late Paleozoic Ice Age in time and space. Geological Society of America, Special Paper 441, pp 41-57

Flügel E (2010) Microfacies of carbonate rocks: analysis, interpretation and application. Springer, Berlin

Frank TD, Birgenheier LP, Montañez IP, Fielding CR, Rygel MC (2008) Late Paleozoic climate dynamics revealed by comparison of ice-proximal stratigraphic and ice-distal isotopic records. In: Fielding CR, Frank TD, Isbell JL (eds) Resolving the Late Paleozoic Ice Age in time and space. Geological Society of America, Special Paper 441, pp 2261-2285

Gong EP, Yang HY, Guan CQ, Sun BL, Yao YZ (2004) Unique recovery of reef communities after $\mathrm{F} / \mathrm{F}$ event in a huge coral reef of Carboniferous, southern China. Sci China Ser D Earth Sci 47:412-418

Gong E, Samankassou E, Guan C, Zhang Y, Sun B (2007) Paleoecology of Pennsylvanian phylloid algal buildups in south Guizhou, China. Facies 53:615-623

Gong EP, Mang YL, Guan CQ, Samankassou E, Sun BL (2007) Paleoecology of Late Carboniferous phylloid algae in southern Guizhou, SW China. Acta Geologica Sinica Engl Ed 81(4):566-572

Gong E, Zhang Y, Guan C, Chen X, Wang Y, Liu M (2012) The Carboniferous reefs in China. Palaeogeography 1:27-42

Gradstein FM, Ogg JG, Schmitz MD, Ogg GM (2012) A geologic time scale, vol 1 of 2. Elsevier B.V., Amsterdam

Guan CQ, Gong EP, Yao YZ, Sun BL (2004) Biocoenose community analysis of Bianping reefs of the Late Carboniferous in southern Guizhou Province. Palaeogeography 6:339-346 (in Chinese, with English abstract)

Guan CQ, Gong EP, Zhang YL, Sun BL, Chang HL (2010) Tubiphytes in reef strata of the late Carboniferous in south Guizhou Province. Acta Sedimentol Sin 28:219-226

Hamilton J (2014) Analysis of a sponge bioherm from the Hermosa Group, Molas Lake Area, Colorado. Honors Projects 116

Haq BU, Schutter SR (2008) A chronology of Paleozoic sea-Level changes. Science 322:64-68

Harrison WE, Curlale JA, Roberts JF (1979) Investigation of Desmoinesian rocks in northeastern Oklahoma for heavy-oil potential.
In: Hyne NJ (ed) Pennsylvanian sandstones of the Mid-Continent. Tulsa Geological Society, Tulsa, pp 337-348

Hautmann M (2006) Shell mineralogical trends in epifaunal Mesozoic bivalves and their relationship to seawater chemistry and atmospheric carbon dioxide concentration. Facies 52:417-433

Heckel PH (2008) Pennsylvanian cyclothems in Midcontinent North America as far-field effects of waxing and waning of Gondwana ice sheets. In: Fielding CR, Frank TD, Isbell JL (eds) Resolving the Late Paleozoic Ice Age in time and space. Geological Society of America, Special Paper 441, pp 275-289

Heckel PH, Cocke JM (1969) Phylloid algal-mound complexes in outcropping Upper Pennsylvanian rocks of mid-continent. Am Asso Petrol Geol Bull 53:1058-1074

Heckel PH, Alekseev AS, Barrick JE, Boardman DR, Goreva NV, Nemyrovska TI, Ueno K, Villa E, Work DM (2007) Cyclothem ["digital"] correlation and biostratigraphy across the global Moscovian-Kasimovian-Gzhelian stage boundary interval (MiddleUpper Pennsylvanian) in North America and eastern Europe. Geology 35:607-610

Henderson GM, Lindsay FN, Slowey NC (1999) Variation in bioturbation with water depth on marine slopes: a study on the Little Bahamas Bank. Mar Geol 160:105-118

Henry LC, Isbell JL, Limarino CO (2008) Carboniferous glaciogenic deposits of the proto-Precordillera of west-central Argentina. In: Fielding CR, Frank TD, Isbell JL (eds) Resolving the Late Paleozoic Ice Age in time and space. Geological Society of America, Special Paper 441, pp 131-142

Hoegh-Guldberg O (2011) Coral reef ecosystems and anthropogenic climate change. Reg Environ Change 11:S215-S227

Holz M, Souza PA, Iannuzzi R (2008) Sequence stratigraphy and biostratigraphy of the Late Carboniferous to Early Permian glacial succession (Itararé subgroup) at the eastern-southeastern margin of the Paraná Basin, Brazil. In: Fielding CR, Frank TD, Isbell JL (eds) Resolving the Late Paleozoic Ice Age in time and space. Geological Society of America, Special Paper 441, pp 115-129

Howarth RJ, McArthur JM (1997) Statistics for strontium isotope stratigraphy: a robust Lowess fit to the marine Sr-isotope curve for 0 to $206 \mathrm{Ma}$, with look-up table for derivation of numeric age. Geology 105:441-456

Huang W, Zhang Y, Guan C, Miao Z, Chen X, Yang Z, Li X, Gong E (2019) Role of calcimicrobes and microbial carbonates in the Late Carboniferous (Moscovian) mounds in southern Guizhou, South China. Palaeogeography 8:26

Isbell JL, Miller MF, Wolfe KL, Lenaker PA (2003) Timing of late Paleozoic glaciation in Gondwana: was glaciation responsible for the development of Northern Hemisphere cyclothems? In: Chan MA, Archer AW (eds) Extreme depositional environments: mega end members in Geological Time. Geological Society of America, Special Paper 370, pp 5-24

Isbell JL, Cole DI, Catuneanu O (2008) Carboniferous-Permian glaciation in the main Karoo Basin, South Africa: stratigraphy, depositional controls, and glacial dynamics. In: Fielding CR, Frank TD, Isbell JL (eds) Resolving the Late Paleozoic Ice Age in time and space. Geological Society of America, Special Paper 441, pp 71-82

Jach R (2001) Lower Jurassic spiculite facies from the Lower subTatric succession of the Tatra Mountains, Poland. Biuletyn Państwowego Instytutu Geologicznego 396:70-71

Kaiser SA, Aretz M, Becker RT (2015) The global Hangenberg crisis (Devonian-Carboniferous transition): review of a first-order mass extinction. Geol Soc Lond Spec Publ 423:387-437

Kiessling W, Aberhan M, Villier L (2008) Phanerozoic trends in skeletal mineralogy driven by mass extinctions. Nat Geosci 1:527-530 
Kim JC, Lee ZI (1996) Marine diagenesis of Lower Ordovician carbonate sediments (Dumugol Formation), Korea: cementation in a calcite sea. Sed Geol 105:241-257

Kleypas JA, Buddemeier RW, Archer D, Gattuso JP, Langdon C, Opdyke BN (1999) Geochemical consequences of increased atmospheric carbon dioxide on coral reefs. Science 284:118-120

Kobayashi F, Altiner D (2008) Fusulinoidean faunas from the Upper Carboniferous and Lower Permian platform limestone in the Hadim area, Central Taurides, Turkey. Riv Ital Paleontol Stratigr 114:191-232

Kumpan T, Bábek O, Kalvoda J, Grygar TM, Frýda J (2014) Sea-level and environmental changes around the Devonian-Carboniferous boundary in the Namur-Dinant Basin (S Belgium, NE France): a multi-proxy stratigraphic analysis of carbonate ramp archives and its use in regional and interregional correlations. Sed Geol 311:43-59

Lees A, Miller J (1985) Facies variation in Waulsortian buildups, Part 2; mid-Dinantian buildups from Europe and North America. Geol J 20:159-180

Leven EYA (2009) Verkhniy Karbon (Pensyl'vaniy) i Perm' Zapadnogo Tetisa: Fuzulinidy, stratigrafiya, paleogeografia. Trudy Geologicheskogo Instituta 590:1-238 ((in Russian))

Leven EYA, Davydov VI (2001) Stratigraphy and fusulinids of the Kasimovian and lower Gzhelian (Upper Carboniferous) in the Southwestern Darvaz (Pamir). Riv Ital Paleontol Stratigr 107:3-46

Leven EYA, Scherbovich SF (1978) Fuzulinidy i Stratigrafiya Assel'skogo Yarusa Darvaza. Akademiya Nauk SSSR, Moscovskoe Obschestovo Ispytateley Prirody, Izdatel'stvo Nauka, Moscow (in Russian)

Leven EYA, Leonova TB, Dmitriev VYU (1992) Perm' DarvazaZaalayskoy zony Pamira: fuzulinidy, ammonoidei, stratigrafiya. Trudy Paleontologicheskogo Instituta 253:1-236 (in Russian)

Lough JM (2012) Small change, big difference: Sea surface temperature distributions for tropical coral reef ecosystems, 19502011. Geophys Res. https://doi.org/10.1029/2012JC008199

Maillet M, Huang WT, Miao ZW, Gong EP, Guan CQ, Zhang YL, Ueno K, Samankassou E (2020) Coral reefs and growth dynamics of a low-angle Carboniferous platform: records from Tianlin, southern China. Sed Geol. https://doi.org/10.1016/j. sedgeo.2019.105550

Mamet B (1991) Carboniferous calcareous algae. In: Riding R (ed) Calcareous algae and stromatolites. Springer, Berlin, pp 370-451

Martin JR, Redfern J, Aiken JF (2008) A regional overview of the Late Paleozoic glaciation in Oman. In: Fielding CR, Frank TD, Isbell JL (eds) Resolving the Late Paleozoic Ice Age in time and space. Geological Society of America, Special Paper 441, pp 175-186

Maynard JR, Leeder MR (1991) On the periodicity and magnitude of Late Carboniferous glacio-eustatic sea-level changes. Geol Soc Lond 149:303-311

McArthur JM, Howarth RJ, Bailey TR (2001) Strontium isotope stratigraphy: lowess version 3: best fit to the marine $\mathrm{Sr}$-isotope curve for 0-509 Ma and accompanying look-up table for deriving numerical age. Geology 109:155-170

McArthur JM, Howarth RJ, Shields GA (2012) Strontium isotope stratigraphy. In: Gradstein FM, Ogg JG, Schmitz MD, Ogg GM (eds) The geologic time scale 2012. Elsevier, Amsterdam, pp 127-144

Merhabi H, Rahimpour-Bonab H, Hajikazemi E, Jamalian A (2015) Controls on depositional facies in Upper Cretaceous carbonate reservoirs in the Zagros area and the Persian Gulf, Iran. Facies $61: 23$

Mory AJ, Redfern J, Martin JR (2008) A review of Permian-Carboniferous glacial deposits in Western Australia. In: Fielding CR, Frank TD, Isbell JL (eds) Resolving the Late Paleozoic Ice Age in time and space. Geological Society of America, Special Paper 441 , pp $29-40$

Nagai K (1985) Reef forming algal chaetetid boundstone found in the Akiyoshi Limestone Group, Southwest Japan. Akiyoshi-dai Mus Nat Hist Bull 20:1-28

Nakazawa T (1997) Sedimentary environments and reef-builders in the Carboniferous of the Omi Limestone Group. Geol Soc Jpn 103:849-868

Nelson WJ, Langenheim RL (1980) Ecological observations on Chaetetes in Southern Nevada. Pac Geol 14:1-22

Oertli HJ (1964) The Venice System for the classification of marine waters according to salinity. Pubblicasioni della Stazione Zoologica di Napoli 33:611-612

Ogar VV (2012) Carboniferous buildups in the Donets Basin (Ukraine). Geologica Belgica 15:340-349

Orlov-Labkovsky O, Bensh FR (2015) Atlas of foraminifera of the Carboniferous and Permian (Cisuralian) of Uzbekistan and adjacent regions, Tien Shan. Pensoft Series Faunistica 114:1-301

Ota AM (1968) The Akiyoshi Limestone: a geosynclinal organic reef complex. Akiyoshi-dai Sci Mus Bull 5:1-44

Pfefferkorn HW, Gastaldo RA, DiMichele WA, Philipps TL (2008) Pennsylvanian tropical floras from the United States as a record of changing climate. In: Fielding CR, Frank TD, Isbell JL (eds) Resolving the Late Paleozoic Ice Age in time and space. Geological Society of America, Special Paper 441, pp 305-316

Pickett JW (1967) The Lower Carboniferous coral faunas from the New England district of New South Wales: geological survey of New South Wales. Palaeontol Mem 15:1-38

Pickett JW, Wu WS (1990) The succession of Early Carboniferous coral faunas in eastern Australia and China. Alcheringa 14:89-108

Ries JB, Stanley SM, Hardie LA (2006) Scleratinian corals produce calcite, and grow more slowly, in artificial Cretaceous seawater. Geol Soc Am 34:525-528

Rocha-Campos AC, dos Santos PR, Canuto JR (2008) Late Paleozoic glacial deposits of Brazil: Paraná Basin. In: Fielding CR, Frank TD, Isbell JL (eds) Resolving the Late Paleozoic Ice Age in time and space. Geological Society of America, Special Paper 441, pp 97-114

Rodríguez S, Somerville ID, Cózar P (2012) Late Viséan coral fringing reef at Tiouinine (Morocco): implications for the role of rugose corals as building organisms in the Mississippian. Geol J 47:462-476

Ross CA, Ross JRP (1987) Late Paleozoic sea levels and depositional sequences. Geology 61:137-149

Ross CA, Ross JRP (1988) Late Paleozoic transgressive-regressive deposition. In: Ross CA, Ross JRP (eds) Sea-level changes: an integrated approach. SEPM, Special Publication 42, pp 227-247

Rygel MC, Fielding CR, Frank TD, Birgenheier LP (2008) The magnitude of Late Paleozoic glacioeustatic fluctuations: a synthesis. Sediment Res 78:500-511

Samankassou E (2001) Internal structure and depositional environment of Late Carboniferous mounds from the San Emiliano Formation, Cármenes Syncline, Cantabrian Mountains, northern Spain. Sediment Geol 145:235-252

Samankassou E (2003) Upper Carboniferous-Lower Permian buildups of the Carnic Alps, Austria-Italy. SEPM Spec Publ 78:201-217

Samankassou E, West RR (2002) Construction versus accumulation in phylloid algal mounds: an example of a small constructed mound in Pennsylvanian of Kansas, USA. Palaeogeogr Palaeoclimatol Palaeoecol 185:379-389

Samankassou E, Mazzini A, Chiaradia M, Spezzaferri S, Moscariello A, Do Couto D (2018) Origin and age of carbonate clasts from the Lusi eruption, Java, Indonesia. Mar Pet Geol 90:138-148

Sandberg PA (1983) An oscillating trend in Phanerozoic non-skeletal carbonate mineralogy. Nature 305:19-22 
Sandberg CA, Ziegler W, Dreesen R, Butler JL (1988) Late Frasnian mass extinction: conodont event stratigraphy, global changes, and possible causes. Global catastrophes in earth history: an interdisciplinary conference on impacts, volcanism, and mass mortality. Lunar and Planetary Institute, Houston, pp 160-161

Schatzinger RA (1983) Phylloid algal and sponge-bryozoan mound-tobasin transition - a late Paleozoic facies tract from Kelly-Snyder Field, west Texas. In: Harris PM (ed) Carbonate buildups-a core workshop. Society of Economic Paleontologists and Mineralogists, Core Workshop 4, pp 244-303

Schenk PE, Hatt BL, Geldsetzer HHJ, Nassichuk WW, Belt ES, Macqueen RW (1984) Depositional environment of the Gays River reef, Nova Scotia, Canada. In: Geldsetzer, HHJ (ed) Part 1: Atlantic coast Basins. IXe Congrès International de Stratigraphie et de Géologie du Carbonifère, 1979, Compte Rendu 3, pp 117-130

Schmitz MD, Davydov VI (2012) Quantitative radiometric and biostratigraphic calibration of the Pennsylvanian-Early Permian (Cisuralian) time scale and pan-Euromerican chronostratigraphic correlation. Geol Soc Am Bull 124:549-577

Scrutton CT (1997) The Palaeozoic corals, I: origins and relationships. Proc Yorks Geol Soc 51:177-208

Scrutton CT (1998) The Late Palaeozoic corals, II: structure, variation and palaeoecology. Proc Yorks Geol Soc 52:1-57

Scrutton C (1999) Paleozoic coals: their evolution and palaeoecology. Geol Today 15:184-193

Seguret M, Moussine-Pouchkine A, Gabaglia GR, Bouchette F (2001) Storm deposits and storm-generated coarse carbonate breccias on a pelagic outer shelf (South-East Basin, France). Sedimentology 48:231-254

Senowbari-Daryan B, Flügel E (1991) Tubiphytes Maslov, an enigmatic fossil: classification, fossil record and significance through time, Part I. Discussion of Late Paleozoic material. In: Barattolo F, De Castro P, Parente M (eds) Studies on Fossil Benthic Algae. Proc. 5th Int. Symp. Fossil Algae, Capri, pp 353-382

Shen J (2002) A Devonian (Givetian) fore-reef slope sequence at Liangshuijing and implication for Devonian platform-to-depression development in Guilin, South China. Carbonates Evaporites 17:25-43

Shen JW, Qing H (2010) Mississippian (Early Carboniferous) stromatolite mounds in a fore-reef slope setting, Laibin, Guangxi, South China. Earth Sci 99:443-458

Shen JW, Webb GE (2005) Metazoan-microbial framework fabrics in a Mississippian (Carboniferous) coral-sponge-microbial reef, Monto, Queensland, Australia. Sed Geol 178:113-133

Sorauf JE (1996) Biocrystallization models and skeletal structure of Phanerozoic corals. Paleobiol Biol Corals 1:159-185

Sorauf JE (1997) Geochemical signature of incremental growth and diagenesis of skeletal structure in Tabulophyllum traversensis (Winchell, 1866). Bolotin de la Real Sociedad Española de Historia Natural 92:77-86

Soreghan GS, Giles KA (1999) Facies character and stratal responses to accommodation in Pennsylvanian bioherms, western Orogrande basin, New Mexico. Sediment Res 69:893-908

Spalding MD, Brown BE (2015) Warm-water coral reefs and climate change. Science 350:769-771

Stanley SM, Hardie LA (1998) Secular oscillations in the mineralogy of reef-building and sediment-producing organisms driven by tectonically forces shifts in seawater chemistry. Palaeogeogr Palaeoclimatol Palaeoecol 144:3-19

Stanley SM, Hardie LA (1999) Hypercalcification: Paleontology links plate tectonics and geochemistry to sedimentology. Geol Soc Am Today 9:1-7

Stollhofen H, Werner M, Stanistreet IG, Armstrong RA (2008) Singlezircon U-Pb dating of Carboniferous-Permian tuffs, Namibia, and the intercontinental deglaciation cycle framework. In: Fielding CR, Frank TD, Isbell JL (eds) Resolving the Late Paleozoic Ice Age in time and space. Geological Society of America, Special Paper 441, pp 83-96

Sugiyama T, Nagai K (1990) Growth forms of auloporid corals in the Akiyoshi Limestone Group, Southwest Japan. Akiyoshi-dai Mus Nat Hist Bull 25:1-25

Sugiyama T, Nagai K (1994) Reef facies and paleoecology of reefbuilding corals in the lower part of the Akiyoshi Limestone Group (Carboniferous), Southwest Japan. Cour Forsch Inst Senckenberg 172:231-240

Sutherland PK, Henry TW (1977) Carbonate platform facies and new stratigraphic nomenclature of the Morrowan Series (Lower and Middle Pennsylvanian), northeastern Oklahoma. Geol Soc Am $88: 425-440$

Swinchatt JP (1969) Algal boring: a possible depth indicator in carbonate rocks and sediments. Geol Soc Am Bull 80:1391-1396

Tan DY (1991) The characteristics of Wengdaowan red algal reef in Ziyun, Guizhou. Explor Exploit Gas 14:78-84 (in Chinese, with English abstract)

Taylor PD, Wilson MA (2003) Palaeoecology and evolution of marine hard substrate communities. Earth Sci Rev 62:1-103

Thompson JB, Newton CR (1988) Late Devonian mass extinction: episodic climatic cooling or warming? In: Devonian of the World: proceedings of the 2nd international symposium on the Devonian System, Memoir 14, volume III, pp 29-34

Toomey DF (1979) Role of archaeolithophyllid algae within a late Carboniferous algal-sponge community, southwestern United States. Centres Rech Explor Prod Elf-Aquitaine Bull 3:843-853

Toomey DF (1991) Late Pennsylvanian phylloid-algal bioherms, Orogrande Basin, south-central New Mexico and west Texas. In: Barker JM, Kues BS, Austin GS, Lucas SG (eds) Geology of the Sierra Blanca, Sacramento, and Capitan Ranges, New Mexico. New Mexico Geological Society 42nd Annual Fall Field Conference Guidebook, pp 213-220

Toomey DF, Wilson JL, Rezak R (1977) Evolution of Yucca Mound Complex, Late Pennsylvanian phylloid-algal buildup, Sacramento Mountains, New Mexico. Am Assoc Petrol Geol Bull 61:2115-2133

Tsien HH, Hou HF, Zhou WL (1988) Devonian reef development and palaeogeographic evolution in South China. In: McMilian JJ, Embry AF, Glass DJ (eds) Devonian of the world. Volume I, Proceedings of the 2nd international symposium on Devonian System. Canadian Society of Petroleum Geology, Calgary, pp 619-634

Udchachon M, Burret C, Thassanapak H, Chonglakmani C, Campbell H, Feng Q (2014) Depositional setting and paleoenvironment of an alatoconchid-bearing Middle Permian carbonate ramp sequence in the Indochina Terrane. J Asian Earth Sci 87:37-55

Vachard D, Pille L, Gaillot J (2010) Palaeozoic foraminifera: systematics, palaeoecology, and responses to global changes. Revue de Micropaléontologie 53:209-254

Wahlman GP (2002) Upper Carboniferous-Lower Permian (Bashkirian-Kungurian) mounds and reefs. In: Kiessling W, Flügel E, Golonka J (eds) Phanerozoic reef patterns. SEPM, Special Publication 72, pp 271-338

Wahlman GP, Konovalova MV (2002) Upper Carboniferous-Lower Permian Kozhim carbonate bank, subpolar pre-Ural Mountains., northern Russia. SEPM Spec Publ 74:219-241

Wang X, Qie W, Sheng Q, Qi Y, Wang Y, Liao Z, Shen S, Ueno K (2013) Carboniferous and Lower Permian sedimentological cycles and biotic events of South China. Geol Soc Lond Spec Publ 376:33-46

Wang W, Garbelli C, Zheng Q, Chen J, Liu X, Wang W, Shen S (2018) Permian ${ }^{87} \mathrm{Sr} /{ }^{86} \mathrm{Sr}$ chemostratigraphy from carbonate 
sequences in South China. Palaeogeogr Palaeolimatol Palaeoecol 500:84-94

Webb GE (1987) Late Visean coral-algal bioherms from the Lion Creek Formation of Queensland, Australia. In: XIe Congrès International de Stratigraphie et de Géologie du Carbonifère, Compte Rendu 3, pp 282-295

Webb GE (1998) Earliest known Carboniferous shallow-water reefs, Gudman Formation (Tn1b), Queensland, Australia: implications for Late Devonian reef collapse and recovery. Geology 26:951-954

Webb GE (2002) Latest Devonian and Early Carboniferous reefs: depressed reef building after the Middle Paleozoic collapse. In: Kiessling W, Flügel E, Golonka J (eds) Phanerozoic reef patterns. SEPM, Special Publication 72, pp 239-269

Webb GE, Sorauf JE (2002) Zigzag microstructure in rugose corals: a possible indicator of relative seawater $\mathrm{Mg} / \mathrm{Ca}$ ratios. Geology $30: 415-418$

Wendt J (1977) Aragonite in Permian reefs. Nature 267:335-337

West RR (1988) Temporal changes in Carboniferous reef mound communities. Palaios 3:152-169

Wiedenmayer F (1980) Spiculites and sponges in the Lower Jurassic of the Western Tethys. In: Hartman WD, Wendt JW, Wiedenmayer F (eds) Living and fossil sponges. Sedimenta, vol 8, pp 135-145

Wilson EC (1963) The tabulate coral Multithecopora Yoh from the Chaetetes-Profusulinella faunizone in eastern Nevada. Palaeontology 37:157-163
Wilson JL (1975) Carbonate facies in geologic history. Springer, New York

Wolfenden EB (1958) Paleoecology of the Carboniferous reef complex and shelf limestones in northwest Derbyshire, England. Geol Soc Am Bull 69:871-898

Woo J, Chough SK (2007) Depositional processes and sequence stratigraphy of the Jigunsan Formation (Middle Ordovician), Taebaeksan Basin, Mideast Korea: implications for basin geometry and sequence development. Geosci J 11:331-355

Wood RA (1987) Biology and revised systematics of some Late Mesozoic stromatoporoids. The Palaeontological Association, London

Wray JL (1977) Late Paleozoic calcareous algae. In: Flugel E (ed) Fossil algae. Springer, Berlin, pp 167-176

Yao L, Wang XD (2016) Distribution and evolution of Carboniferous reefs in South China. Palaeoworld 25:362-376

Zhang Y, Gong E, Wilson MA, Guan C, Sun B, Chang H (2009) Paleoecology of a Pennsylvanian eucrusting colonial rugose coral in south Guizhou, China. Palaeogeogr Palaeoclimatol Palaeoecol 280:507-516

Zhang YL, Gong EP, Wilson MA, Guan CQ, Sun BL (2010) A large coral reef in the Pennsylvanian of Ziyun County, Guizhou (South China): the substrate and initial colonization environment of reefbuilding corals. Asian Earth Sci 37:335-349 